\title{
PENGGUNAAN METODE TEKNIK JIGSAW DALAM UPAYA MENINGKATKAN PRESTASI BELAJAR IPS PESERTA DIDIK KELAS IX.F SMPN 33 SURABAYA MATERI BENUA DAN SAMUDRA DI BUMI
}

\author{
Juliastuti \\ SMP Negeri 33 Surabaya \\ mbahtu.33@gmail.com
}

\begin{abstract}
Abstrak
Masalah yang diteliti dalam penelitian ini adalah apakakah dengan menggunakan metode pembelajaran kooperatif type jigsaw dapat meningkatkan prestasi belajar peserta didik kelas IX.F SMP Negeri 33 Surabaya Kota Surabaya pada mata pelajaran IPS semester II Tahun Pelajaran 2012/2013. Lokasi penelitian ini di SMP Negeri 33 Surabaya Kota Surabaya. Hipotesis pada penelitian ini adalah dengan menggunakan metode pembelajaran kooperatif type jigsaw pada pelajaran IPS dapat meningkatkan prestasi belajar peserta didik kelas IX.F SMP Negeri 33 Surabaya Kota Surabaya T.A 2012/2013. Tujuan dari penelitian ini adalah (1). Mengetahui dan mendeskripsikan proses pembelajaran mata pelajaran IPS pada peserta didik Kelas IX.F, (2). Mengetahui dan mendeskripsikan prestasi belajar peserta didik dalam mata pelajaran IPS dengan strategi pembelajaran yang digunakan oleh guru, (3). Mengetahui dan mendeskripsikan dampak penggunaan strategi pembelajaran dengan teknik jigsaw terhadap prestasi belajar mata pelajaran IPS pada peserta didik Kelas IX.F. Berdasarkan analisis data yang diperoleh bahwa pada observasi siklus I dari 34 orang peserta didik diperoleh bahwa 15 orang peserta didik $45.71 \%$ yang telah tuntas dengan baik, dan sebanyak 19 orang peserta didik $54.29 \%$ yang belum tuntas dengan nilai rata - rata 64.00. Kemudian pada siklus II prestasi belajar peserta didik meningkat menjadi 34 orang $100 \%$ yang telah tuntas dengan rata - rata $80,00 \%$. Dengan demikian dapat disimpulkan bahwa penggunaan metode pembelajaran kooperatif tipe jigsaw dapat meningkatkan prestasi belajar peserta didik pada pelajaran IPS materi Benua dan Samudra di Bumi di kelas IX.F. Oleh karenanya guru perlu meningkatkan keterampilan mengajarnya dengan menggunakan metode pembelajaran kooperatif type jigsaw sebagai salah satu upaya yang dilakukan untuk meningkatkan prestasi belajar peserta didik pada pelajaran IPS khususnya materi Benua dan Samudra di Bumi.
\end{abstract}

Kata Kunci: Teknik Jigsaw, Prestasi Belajar, IPS

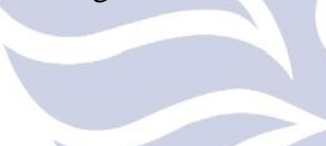

\section{Abstract}

Issues examined in this study is apakakah by using cooperative learning jigsaw type can improve learning achievement IX.F grade students of SMP Negeri 33 Surabaya Surabaya in social studies second semester in the academic year 2012/2013. The location of this research in SMP Negeri 33 Surabaya Surabaya.

The hypothesis of this research is to use cooperative learning method jigsaw type in social studies can improve the performance of learners class IX.F SMP Negeri 33 Surabaya Surabaya T.A 2012/2013. The purpose of this study were (1). Knowing and describe the process of learning social studies in Grades IX.F learners, (2). Know and to describe achievements of learners in social studies with learning strategies used by the teacher, (3). Know and to describe the impact of the use of learning strategy and jigsaw techniques on the learning achievement in social studies classes of learners IX.F.

Based on the analysis of data obtained in the observation that the first cycle of 34 students found that 15 votes $45.71 \%$ of learners who have completed well, and as many as 19 students who have not completed $54.29 \%$ by value - average 64.00 . Then in the second cycle of learning achievement of students increased to 34 people who have completed $100 \%$ with the average - average $80.00 \%$.

It can be concluded that the use of cooperative learning method jigsaw type can improve learning achievement of students in social studies materials continent and the ocean on the Earth in the classroom IX.F. Therefore, teachers need to improve their teaching skills by using cooperative learning jigsaw type as one of the efforts to improve learning achievement of students in social studies material in particular continent and ocean on Earth.

Keywords: Jigsaw Technique, Learning Achievement, IPS 


\section{PENDAHULUAN}

Tantangan terhadap peningkatan mutu, relevansi, dan efektivitas pendidikan sebagai tuntutan nasional sejalan dengan perkembangan dan kemajuan masyarakat, berimplikasi secara nyata dalam program pendidikan dan kurikulum sekolah. Tujuan dari program kurikulum dapat tercapai dengan baik jika programnya didesain secara jelas dan aplikatif. Dalam hubungan inilah para guru dituntut untuk memiliki kemampuan mendesain programnya dan sekaligus menentukan strategi instruksional yang harus ditempuh. Para guru harus memiliki keterampilan memilih dan menggunakan metode mengajar untuk diterapkan dalam sistem pembelajaran yang efektif (Hamalik, 2001).

Oleh karena itu, guru dipandang sebagai agen modernisasi dalam segala bidang. Usaha utama yang dapat dilakukan oleh guru adalah melalui program pendidikan bagi para peserta didik. Dalam melakukan usaha pencapaian tujuan pendidikan di sekolah tersebut, guru berperan penting dalam menggunakan metode dan cara untuk mencapai hasil belajar yang optimal. Untuk mencapai tujuan tersebut sangat didukung oleh strategi yang digunakan guru dalam proses belajar mengajar.

Menurut Santoso (2002) mengatakan bahwa proses belajar mengajar merupakan suatu proses yang mengandung serangkaian perbuatan guru dan peserta didik atas dasar hubungan timbal balik yang berlangsung dalam situasi edukatif untuk mencapai tujuan tertentu. Interaksi dan hubungan timbal balik antara guru dan peserta didik itu merupakan syarat utama bagi berlangsungnya proses belajar mengajar. Berdasarkan pendapat tersebut Kusaeri (2001), mengatakan bahwa guru sebagai pelaksana terdepan, harus dapat mengantisipasi perkembangan ini, dengan memberikan materi pembelajaran dengan strategi pengajaran yang diinginkan oleh peserta didik. Sehingga materi yang dipelajari akan dapat diterima dengan baik oleh peserta didik dan guru dapat memberikan dengan baik pula. Hal ini akan dapat terlaksana apabila guru dapat menyesuaikan dengan perkembangan jaman dalam menyampaikan materi dengan strategi belajar yang dapat meningkatkan kreativitas peserta didik juga. Sebab jika tidak dibarengi dengan pengetahuan guru yang baik, tidak menutup kemungkinan bahwa pengetahuan guru akan kalah dan tertinggal dari pengetahuan peserta didik.

Artinya dengan menggunakan strategi pembelajaran yang benar akan mengarahkan peserta didik pada ketercapaian tujuan pendidikan yang dirumuskan. Sebagai contoh adalah mata pelajaran IPS untuk peserta didik Kelas IX.F. Ada beberapa temuan yang dialami oleh peneliti bahwa salah satu indikator rendahnya prestasi peserta didik Sekolah Menengah Pertama ini adalah kurangmya partisipasi peserta didik dalam mengikuti mata pelajaran ini. peserta didik cenderung pasif, keberanian untuk bertanya maupun menjawab pertanyaan juga kurang. Sehingga proses kegiatan belajar mengajar terkesan kurang menunjukkan aktivitas yang berarti. Akhirnya guru terlihat aktif dalam proses belajar mengajar, sedangkan peserta didiknya pasif. Hal ini disebabkan oleh kecenderungan guru lebih senang menggunakan strategi belajar yang cepat dan praktis untuk mentransfer ilmu pengetahuan kepada peserta didik, sementara peserta didik sudah bosan dengan strategi yang diberikan oleh guru. Kondisi seperti ini jelas berakibat pada prestasi belajar peserta didik dalam mata pelajaran IPS sangat rendah.

Dewasa ini telah dikembangkan suatu pendekatan pembelajaran kooperatif untuk menghasilkan tujuan belajar yang baik. Mengapa harus kooperatif? Menurut Nurhadi (2002) sejauh ini pendidikan di Indonesia masih didominasi oleh pandangan bahwa pengetahuan sebagai Perangkat fakta-fakta yang harus dihafal. Kelas masih berfokus pada guru sebagai sumber utama pengetahuan, kemudian ceramah menjadikan pilihan utama strategi belajar. Untuk itu diperlukan sebuah strategi baru yang lebih memberdayakan peserta didik. Sebuah strategi belajar yang tidak mengharuskan peserta didik menghafal fakta-fakta, tetapi sebuah strategi yang mendorong peserta didik mengkonstruksikan pengetahuan dibenak mereka sendiri.

Kenyataan di lapangan pendidikan proses pencapaian pembelajaran di SMP Negeri 33 Surabaya Kota Surabaya, masih menggunakan paradigma lama walaupun sekarang kurikulum telah berkembang menuju Kurikulum KTSP. Sehingga tidak menutup kemungkinan hasil belajar yang dicapai oleh peserta didikpun terkesan monoton, karena hanya menghafal suatu fakta dan guru dipandang sebagai sumber utama dalam belajar. Salah satu hasil belajar yang diperoleh adalah mata pelajaran IPS untuk Kelas IX.F. Belajar IPS lebih mengutamakan pada kemampuan berpikir logika, tidak menghafalkan suatu 
fakta. Namun kenyataan ini masih terlihat dalam pencapaian hasil belajar di Kelas IX.F.

Berdasarkan pada fenomena tersebut, peneliti akan melakukan suatu penelitian tindakan kelas dengan melakukan perubahan strategi belajar mengajar mata pelajaran IPS pada peserta didik Kelas IX.F dengan menggunakan teknik Jigsaw.

$$
\text { Menurut }
$$

Suhardi

mengatakan bahwa teknik Jigsaw adalah suatu teknik belajar kelompok yang digambarkan sebagai berikut:

(a) Satu kelas dibagi dalam kelompok-kelompok kecil, banyaknya anggota kelompok disesuaikan dengan banyaknya masalah/problem yang ditawarkan guru. Kelompok-kelompok ini disebut dengan home group

(b) Setiap anggota home group diberi problem yang berbeda-beda, tapi masing-masing home group di beri persoalan yang sama. Dengan batasan waktu tertentu masing-masing anggota menyelesaikan problem secara individu,

(c) Anggota home group akan berpencar dan membentuk kelompok baru yang membawa persoalan sama. Kelompok ini disebut expert group (kelompok ahli). Di kelompok inilah mereka berdiskusi untuk menyamakan persepsi atas jawaban mereka, dan (d) Setelah selesai mereka kembali ke home group dan anggota-anggota mensosialisasikan hasil/jawaban dari kelompok ahli.

Dengan menggunakan strategi belajar teknik jigsaw ini diharapkan hasil belajar mata pelajaran IPS pada peserta didik Kelas IX.F mencapai suatu hasil yang optimal. Beberapa alasan peneliti mengembangkan teknik jigsaw pada pembelajaran mata/ pelajaran IPS disebabkan karena didalam kurikulum mata pelajaran IPS dapat membantu peserta didik untuk: (1) menjalani kehidupan sehari-hari secara efektif, (2) memahami dunianya dan hal-hal yang mempengaruhinya, (3) memanfaatkan kesempatan untuk mengembangkan kemampuan berfikir kreatif, fleksibel, dan inovatif, (4) mengembangkan pengertian tentang konsep-konsep IPS, (5) menilai dan mempelajari IPS, (6) memahami bahwa IPS juga mempunyai peranan yang besar terhadap perkembangan budaya, (7) membuat penilaian tentang nilai IPS yang berkenaan dengan perkembangan dan peradaban suatu bangsa, (8) bertanggung jawab terhadap pelestarian nilai-nilai IPS, (9) memberikan pemecahan pada dilema moral sehubungan dengan nilai-nilai IPS, dan (10) menyiapkan diri untuk studi pada tingkatan yang lebih lanjut.

Berdasarkan fenomena-fenomena tersebut, peneliti bermaksud melakukan suatu penelitian tindakan (action research) tentang strategi pembelajaran dengan menggunakan teknik jigsaw dalam menyampaikan materi pelajaran IPS pada peserta didik Kelas IX.F dengan harapan penggunaan teknik jigsaw ini dapat membantu meningkatkan prestasi peserta didik dalam belajar mata pelajaran IPS.

Berdasarkan pada latar belakang masalah tersebut, dapat dirumuskan beberapa permasalahan sebagai berikut:

1. Bagaimanakah proses pembelajaran mata pelajaran IPS pada peserta didik Kelas IX.F ?

2. Apakah prestasi belajar peserta didik dalam mata pelajaran IPS dipengaruhi oleh strategi pembelajaran yang digunakan oleh guru ?

3. Bagaimanakah dampak penggunaan strategi pembelajaran dengan teknik jigsaw terhadap prestasi belajar mata pelajaran IPS pada peserta didik Kelas IX.F ?

Sedangkan tujuan penelitian sebagai

berikut:

1. Mengetahui dan mendeskripsikan proses pembelajaran mata pelajaran IPS pada peserta didik Kelas IX.F.

2. Mengetahui dan mendeskripsikan prestasi belajar peserta didik dalam mata pelajaran IPS dengan strategi pembelajaran yang digunakan oleh guru.

3. Mengetahui dan mendeskripsikan dampak penggunaan strategi pembelajaran dengan teknik jigsaw terhadap prestasi belajar mata pelajaran IPS pada peserta didik Kelas IX.F.

Berdasarkan pada tujuan penelitian tersebut, penelitian "Penggunaan Metode Teknik Jigsaw Dalam Upaya Meningkatkan Prestasi Belajar IPS peserta didik Kelas IX.F SMPN 33 Surabaya Materi Benua dan Samudra di Bumi, diharapkan dapat menghasilkan temuan-temuan mengenai strategi pembelajaran dengan teknik jigsaw pada mata pelajaran IPS pada peserta didik Kelas IX.F SMP Negeri 33 Surabaya Kota Surabaya. Disisi lain diharapkan penelitian ini bermanfaat bagi peneliti : Menambah wawasan dan pengetahuan dalam meningkatkan kualitas 
pendidikan mata pelajaran IPS pada peserta didik Kelas IX.F SMP Negeri 33 Surabaya Kota Surabaya dengan strategi pembelajaran teknik jigsaw, dan pada SMP pada umumnya. Dan bagi sekolah : a) Memberikan bahan masukan dalam rangka pengembangan kurikulum sekolah agar tidak terpaku dengan cara-cara konvensional yang mapan, namun perlu disesuaikan dengan perubahan atau inovasi penyelenggaraan proses pembelajaran yang disesuaikan dengan tuntutan perkembangan zaman. b)Sebagai sarana untuk mengetahui atau menemukan hambatan dan kelemahan penyelenggaraan pembelajaran serta sebagai upaya memperbaiki dan mengatasi masalah-masalah pembelajaran yang dihadapi di kelas, sehingga dapat menemukan cara yang tepat untuk meningkatkan prestasi belajar peserta didik sesuai dengan situasi dan kondisi sekolah.

Serta bagi Dinas Pendidikan Kota Surabaya : Sebagai masukan dalam proses pelaksanaan pembelajaran agar mengikuti, memperhatikan, dan menerapkan hasil yang diperoleh dari penelitian ini, sehingga kelemahan pelaksanaan pembelajaran di lapangan pendidikan dapat diperbaiki sesuai dengan saran dan rekomendasi dari hasil-hasil penelitian tindakan kelas.

\section{Rencana Tindakan}

Penelitian Tindakan Kelas dengan judul Meningkatkan Prestasi Belajar IPS Materi Benua dan Samudra di Bumi Dengan Metode Teknik Jigsaw Peserta Didik Kelas IX.F, merumuskan suatu rencana tindakan sebagai berikut. Rencana tindakan yang dilakukan peneliti dalam penelitian tindakan kelas (action research) ini terbagi menjadi 4 siklus kegiatan penelitian, sesuai dengan rancangan penelitian meliputi planning, acting, observing, dan reflecting, yang dikelompokkan pada kegiatan yang dinamakan siklus.

Siklus 1 planning menentukan materi pembahasan dalam materi yang akan dibahas adalah Bahasan Benua dan Samudra di Bumi dengan sub pembahasan: letak/posisi benuabenua dan samudera-samudera di muka bumi pada peta, (2) batas-batas wilayah geografis tiap-tiap benua dengan bantuan peta dunia, (3) 4 karakteristik tiap-tiap benua di muka bumi (4) 3 karakteristik tiap-tiap samudera di muka bumi (5) pembagian kawasan benua-benua di muka bumi selain benua Ausralia dan Antartika (6) contoh negara-negara di tiap-tiap kawasan benua. Siklus 2 acting membahas dan melakukan refleksi pada kegiatan siklus 1 , dengan melengkapi/menambahkan sarana penunjang keberhasilan belajar yang telah dilakukan pada kegiatan pembelajaran pada siklus $l$. Siklus 3 observing melakukan kegiatan yang merupakan follow up dari kegiatan siklus 1 dan siklus 2, berupa diskusi kelompok dalam memecahkan masalah materi pelajaran, berdasarkan observasi dan pengalaman kegiatan pada siklus sebelumnya, dan Siklus 4 reflecting berupa kegiatan refleksi pada kegiatan siklus 1, siklus 2, dan siklus 3. Dalam siklus ini tujuan utamanya adalah untuk mengatasi kesulitan yang muncul dalam proses pembelajaran.

Pada akhir kegiatan pembelajaran dengan strategi pembelajaran menggunakan teknik jigsaw guru melakukan evaluasi. Hal ini dimaksudkan untuk mengetahui tingkat keberhasilan prestasi belajar peserta didik dalam mengikuti kegiatan belajar mengajar dengan menggunakan strategi pembelajaran teknik jigsaw pada mata pelajaran IPS Kelas IX.F.

Setelah melakukan evaluasi pembahasan berdasarkan siklus tersebut, diharapkan peneliti dapat mengetahui dampak yang diperoleh dengan strategi pembelajaran dengan menggunakan teknik jigsaw ini.

\section{METODE}

Rancangan dalam penelitian ini adalah rancangan penelitian tindakan. Menurut Waseso (1994) penelitian tindakan merupakan proses daur ulang, mulai tahap perencanaan, pelaksanaan tindakan dan pemantauan, refleksi yang mungkin diikuti dengan perencanaan ulang.

Penelitian tindakan merupakan merupakan intervensi skala kecil terhadap tindakan dunia nyata dan pemeriksaan cermat terhadap pengaruh intervensi tersebut (Cohen dan Mantion, (1980) yang dikutip oleh Zuriah, (2003)

Rancangan dalam penelitian ini direncanakan melalui beberapa tahap perencanaan, diantaranya: (1) refleksi awal, (2) peneliti merumuskan permasalahan secara operasional, (3) peneliti merumuskan hipotesis tindakan, dan (4) menetapkan dan merumuskan rancangan tindakan.

Rancangan penelitian tindakan ini dilakukan secara kolaboratif antara peneliti dengan guru mata pelajaran IPS pada sekolah lain yang berada di lingkup Dinas Pendidikan Kota Surabaya. Dengan kolaboratif ini diharapkan terjadi interaksi antara peneliti dengan guru IPS untuk peserta didik SMP 
Kelas IX.F, dalam rangka mencapai kesempurnaan hasil penelitian yang dilakukan oleh peneliti.

Penelitian ini dilakukan pada peserta didik Kelas IX.F di SMP Negeri 33 Surabaya. Subjek penelitian ini sejumlah 35 peserta didik Kelas IX.F di SMP Negeri 33 Surabaya. Tindakan yang dilakukan adalah penerapan strategi pembelajaran dengan teknik jigsaw, pada proses pembelajaran mata pelajaran IPS.

Rencana penelitian tindakan kelas (action research) ini, terbagi menjadi 4 tahap. Yaitu, planning, acting, observating, dan reflection. Adapun langkahlangkah perencanaan yang dilakukan oleh peneliti dalam penelitian ini adalah:

\section{Merumuskan tujuan} penelitian. Tujuan penelitian yang dimaksud adalah tujuan meningkatkan prestasi belajar mata pelajaran IPS dengan menggunakan teknik jigsaw. Selanjutnya memberikan materi yang akan dipelajari sebagai persiapan awal dalam penelitian ini. Dengan memberikan materi ini diharapkan peserta didik akan mempelajari lebih dahulu materi dan tujuan pembelajaran yang akan dicapai.

2. Setelah memberikan materi pada peserta didik, selanjutnya guru melakukan proses pembelajaran dengan menggunakan strategi pembelajaran dengan teknik jigsaw pada pelajaran IPS untuk peserta didik Kelas IX.F. Tahap ini peneliti sudah masuk kelas sebagai subyek penelitian dengan menyampaikan pokok permasalahan mata pelajaran IPS. Peneliti membagi peserta didik menjadi beberapa kelompok dengan berdasar pada keheterogenan peserta didik (usia, gender, agama, dan kemampuan)

3.Selama melakukan kegiatan pertama dan kedua, hal yang terpenting adalah observasi objek penelitian dengan tujuan untuk mengenal segala unsur lingkungan fisik dan alam sekitar khususnya kelas yang digunakan sebagai obyek penelitian. Menurut Nasution (1988) yang dimaksud dengan observasi adalah dasar semua ilmu pengetahuan selama di lapangan, peneliti berusaha berinteraksi dengan subjek secara aktif, sebab observasi adalah kegiatan selektif dari suatu proses aktif, untuk mengetahui keadaan obyek penelitian sebelum peneliti melakukan penelitian sesuai dengan kenyataan yang ada.

4. Pengumpulan data awal untuk pemfokusan masalah penelitian dilakukan peneliti dengan mengadakan pengamatan langsung. Hal ini dimaksudkan, agar mendapatkan data yang valid dan reliable sesuai dengan kondisi obyek penelitian. Dengan melakukan pengamatan langsung, maka peneliti akan memperoleh catatan lapangan yang dapat dipertanggungjawabkan. Moleong (1995) menyebutkan bahwa catatan lapangan merupakan jantungnya penelitian kualitatif. Selanjutnya Moleong (1995) mengatakan bahwa penelitian kualitatif memposisikan manusia sebagai instrumen utama dalam pengumpulan data. Kehadiran peneliti di lapangan sangat diutamakan, sebab dalam pengumpulan data harus dilakukan dalam situasi yang sebenarnya.

Menurut Lincoln dan Guba (1981) menyebutkan pentingnya pengamatan dalam penelitian kualitatif, diantaranya: 1) pengamatan ini didasarkan pada pengamatan langsung, 2) dapat mencatat perilaku dan kejadian yang terjadi pada kondisi yang sebenarnya, 3) memungkinkan mencatat situasi yang berkaitan dengan pengetahuan proposisional maupun pengetahuan yang langsung diperoleh dari data, 4) menghindari bias pada saat wawancara, 5) peneliti mampu memahami situasi rumit, dan 6) membantu bila tidak memungkinkan menggunakan teknik komunikasi.

5. Melakukan kegiatan pada setiap siklus yang dimulai dari siklus 1 dan seterusnya, dengan membahas materi Benua dan Samudra di Bumi.

6. Melakukan proses

kegiatan pembelajaran mata pelajaran IPS dengan teknik jigsaw melalui diskusi antara peserta didik dengan peserta didik, peserta didik dengan guru.

7. Mengumpulkan data dari hasil pelaksanaan penelitian yang dilakukan oleh peneliti, berdasarkan pada pelaksanaan proses belajar mengajar dan hasil belajar obyek penelitian yaitu peserta didik Kelas IX.F di SMP Negeri 33 Surabaya Kota Surabaya.

A 8. Setelah data terkumpul selanjutnya mengidentifikasi, dan langkah selanjutnya adalah mendeskripsikan hasil identifikasi. Utamanya adalah tinjauan dari hasil belajar yang diperoleh peserta didik dari kegiatan evaluasi yang dilakukan oleh guru.

Langkah terakhir melakukan refleksi terhadap hasil penelitian tindakan yang dilakukan selama kegiatan pembelajaran pada tahap-tahap sebelumnya. Selanjutnya mendeskripsikan dan memaparkan hasil penelitian secara kualitatif sesuai dengan fokus penelitian. Pada akhirnya hasil deskripsi tersebut 
Penggunaan Metode Teknik Jigsaw dalam Upaya Meningkatkan Prestasi Belajar IPS Peserta Didik Kelas IXF SMPN 33 Surabaya Materi Benua dan Samudra di Bumi

Juliastuti

dibuktikan dengan pembuktian hipotesis yang diajukan oleh peneliti dari penelitian tindakan kelas ini.

Menurut Zuriah (2003), ada 5 jenis instrumen yang digunakan dalam penelitian tindakan. Diantaranya observasi, wawancara, catatan lapangan, angket, dan dokumentasi.

Dalam penelitian ini instrumen yang digunakan meliputi: (1) observasi, (2) wawancara, dan (3) dokumentasi

Observasi diartikan sebagai pengamatan dan pencatatan secara sistematik terhadap gejala yang tampak pada objek penelitian (Zuriah, 2003). Pengamatan dan pencatatan yang dilakukan terhadap objek di tempat terjadi atau berlangsungnya peristiwa.

Ada dua jenis observasi yang dilakukan, diantaranya: (a) Observasi langsung, yaitu observasi yang dilakukan dimana observer berada bersama objek yang diselidiki, dan (b) Observasi tidak langsung, yaitu observasi atau pengamatan yang dilakukan tidak pada saat berlangsungnya suatu peristiwa yang akan diteliti. Dengan menggunakan teknik ini, melakukan catatan terhadap hasil observasi dengan menggunakan daftar cek (chek list)

Dalam penelitian ini metode observasi yang dilakukan oleh peneliti adalah pengamatan berperan serta. Menurut Bogdan \& Biklen (1982) ketiga teknik tersebut merupakan teknik-teknik dasar yang digunakan dalam penelitian kualitatif.

Menurut Bogdan (1973) dalam Moleong (2001) mendefinisikan bahwa secara tepat pengamatan berperanserta sebagai penelitian yang bercirikan interaksi sosial yang memakan waktu cukup lama antara peneliti dengan subjek dalam lingkungan subjek, dan selama itu data dalam bentuk catatan lapangan dikumpulkan secara sistematis dan berlaku tanpa gangguan.

Spradley (1980) membagi tiga tahap pengamatan berperan serta dalam penelitian kualitatif, diantaranya; (a) Dimulai dari pengamatan-pengamatan yang bersifat memeriksa (descriptive observations) secara luas, dengan melukiskan situasi sosial secara umum yang ada di lokasi penelitian, (b) kemudian dilanjutkan dengan pengamatanpengamatan yang lebih terfokus

(focused observations) untuk menemukan kategori-kategori utama tentang fokus penelitian, dan (c) setelah itu diadakan pengamatan-pengamatan yang bersifat selektif (selective observations) untuk menemukan kategori-kategori yang lebih rinci tentang sub-sub fokus penelitian.
Tiga tahap tersebut juga dilakukan oleh peneliti dalam penelitian Pembelajaran kooperatif dengan teknik jigsaw Sebagai Upaya Meningkatkan Prestasi Belajar IPS Materi Benua dan Samudra di Bumi dengan Metode Teknik Jigsaw peserta didik Kelas IX.F di SMP Negeri 33 Surabaya Kota Surabaya Tahun Ajaran 2012/2013.

$$
\text { Selanjutnya Spradley (1980) }
$$

menjabarkan lima tipe keterlibatan peneliti dalam partisipasi observasi yang terbuat dalam tabel sebagai berikut :

Tabel 3.1 Tipe Keterlibatan Peneliti dalam Partisipasi Observasi (Sumber: Spradley, 1980:58)

\begin{tabular}{|c|c|}
\hline $\begin{array}{c}\text { DEGREE OF } \\
\text { INVOLVEMENT }\end{array}$ & $\begin{array}{c}\text { TYPE OF } \\
\text { PARTICIPATION }\end{array}$ \\
\hline \multirow{4}{*}{ High } & Complete \\
\hline & Active \\
\hline & Moderate \\
\hline & Passive \\
\hline $\begin{array}{c}\text { (No } \\
\text { involvement) }\end{array}$ & Nonparticipation \\
\hline
\end{tabular}

participation)

Pada tipe ini peneliti dalam melakukan penelitian tidak berpartisipasi. Artinya peneliti hanya melakukan pengamatan (melihat) secara pasif dan menjauhi agar tidak terlibat dalam aktivitas obyek penelitian.

b) partisipasi pasif (passive participation)

Tahap ini peneliti ikut atau berada dalam obyek penelitian, tetapi tidak berpartisipasi atau interaksi dengan obyek penelitian. Peneliti hanya mondar-mandir sebagai penonton saja.

c) partisipasi moderat (moderat participation)

Peneliti sudah pada konteks untuk menjaga keseimbangan antara seseorang yang berada di dalam (insider) dan menjadi seseorang yang berada di luar (outsider) ataupun terlibat dan mengamati.

participation)

d) partisipasi aktif (active

Pada tahap ini peneliti secara aktif melakukan apa yang dilakukan oleh personal-personal sekolah.

e) Partisipasi secara total (complete or ordinary participation) 
Tipe ini merupakan tahap tertinggi dalam keterlibatan peneliti sebagai observer purtisipant. Peneliti total melakukan seperti apa yang dikerjakan oleh personal-personal sekolah dalam memperoleh data penelitian.

Wawancara merupakan metode pengumpulan data yang menghendaki komunikasi langsung antara peneliti dengan responden (Zuriah, 2003) Wawancara merupakan salah satu prosedur terpenting untuk mengumpulkan data dalam penelitian kualitatif, sebab banyak informasi yang diperoleh peneliti melalui wawancara. 138 Menurut Arifin (1998) yang dimaksud dengan wawancara adalah suatu percakapan yang bertujuan memperoleh konstruksi yang terjadi sekarang tentang orang, kejadian, aktivitas, organisasi, perasaan, motivasi, pengakuan, kerisauan dan sebagainya. Menurut Lincoln dan Guba yang dikutip oleh Moleong (2000), maksud mengadakan wawancara antara lain untuk mengkonstruksi mengenai orang, kejadian, kegiatan organisasi, perasaan, motivasi, tuntutan kepedulian dan lain-lain.

Wawancara dilakukan peneliti untuk memperoleh data sesuai dengan kenyataan pada saat peneliti melakukan wawancara. Wawancara dalam penelitian ini ditujukan kepada peserta didik Kelas IX.F di SMP Negeri 33 Surabaya Kota Surabaya dan guru mata pelajaran IPS di SMP lainnya. Wawancara dalam penelitian ini menggunakan jenis wawancara mendalam yang tidak terstruktur. Sebab dalam wawancara tidak terstruktur akan diperoleh informasi sebanyak-banyaknya yang rahasia, dan sensitif sifatnya sekalipun serta memungkinkan sekali dicatat semua respons afektif informan yang tampak selama wawancara berlangsung (Bafadal, 1994). Namun dalam pelaksanaan wawancara tersebut tetap mengacu pada Guba dan Lincoln (Bafadal, 1994) bahwa sebelum melakukan wawancara terlebih dahulu disusun garis-garis besar pertanyaan yang disampaikan kepada informan berdasarkan pada fokus dan sub fokus penelitian.

\section{Dokumentasi}

Menurut Zuriah (2003) teknik ini adalah cara mengumpulkan data melalui peninggalan tertulis, terutama berupa arsip-arsip dan termasuk juga buku-buku tentang pendapat, teori, dalil atau hukum- hukum lain yang berhubungan dengan masalah penelitian.

Guba \& Lincoln (1981) mengatakan bahwa dokumen dan record dapat digunakan untuk keperluan penelitian karena: (1) merupakan sumber yang stabil, kaya dan mendorong, (2) berguna sebagai bukti untuk suatu pengujian, (3) sifatnya alamiah sesuai dengan konteks, (4) hasil pengkajian akan membuka kesempatan untuk lebih memperluas pengetahuan yang diselidiki.

\section{Teknik Analisis Data}

Analisis menurut Patton (1980) adalah proses mengatur urutan data, mengorganisasikannya ke dalam suatu pola kategori dan satuan uraian dasar. Analisis data adalah proses yang merinci usaha secara formal untuk menemukan tema dan merumuskan hipotesis sesuai dengan arah dan saran data yang ada. Menurut Nasution (1992) Analisis adalah proses penyusunan data agar dapat ditafsirkan.

Bogdan dan Biklen (1982), mengatakan analisis data merupakan proses mencari dan mengatur secara sistematis transkrip wawancara, catatan lapangan dan bahan-bahan lain yang telah dihimpun oleh peneliti. Pekerjaan analisis meliputi kegiatan mengerjakan data, manata, membagi menjadi satuan-satuan yang dapat dikelola, mensintesiskannya, mencari pola, menemukan apa yang penting dan apa yang akan peneliti laporkan. Miles dan Hubermen (1984) mengatakan analisi data perlu dilakukan secara terus menerus selama penelitian berlangsung. Selanjutnya Nasution (1988) mengatakan bahwa analisis data adalah proses menyusun, mengkategorikan data, mencari pola atau tema dengan maksud untuk memahami maknanya.

Moleong (1995:103) mengemukakan, "analisis data adalah proses pengorganisasian dan pengurutan data ke dalam pola, kategori dan satuan uraian dasar, sehingga dapat ditemukan tema seperti yang disarankan oleh data." Teknik analisis data yang digunakan dalam penelitian ini adalah analisis deskriptif. Dengan maksud bahwa penelitian deskriptif dirancang untuk memperoleh informasi tentang status gejala pada saat penelitian dilakukan. Setelah data hasil penelitian terkumpul maka, selanjutnya data tersebut disusun secara sistematis. Dengan cara diorganisir, kemudian dikerjakan yang akhirnya data tersebut diungkap permasalahan yang penting sesuai dengan topik yang sesuai dengan permasalahan. 
Selanjutnya Miles \& Hubermen (1984) menerapkan tiga alur kegiatan dalam analisis deskriptif yang menjadi satu kesatuan yang tak dapat terpisahkan, yaitu: (1) reduksi data, (2) penyajian data, dan (3) penarikan kesimpulan atau verifikasi.

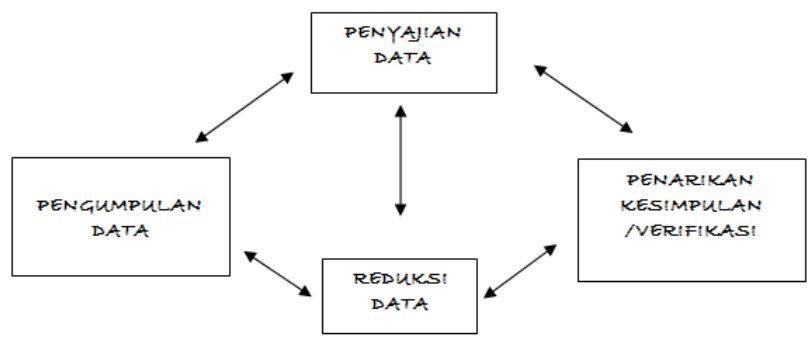

cheres rata nasas

139 yang muncul dan catatan-catatan di lapangan (Miles \& Hubermen, 1984).

Laporan lapangan sebagai bahan mentah direduksi, diringkas, ditonjolkan pokok-pokoknya dan disusun lebih sistematis, sehingga lebih mudah dikendalikan. Data yang direduksi dapat memberikan gambaran yang lebih jelas tentang hasil pengamatan, juga memberikan kemudahan bagi peneliti dalam mendapatkan kembali data yang diperoleh jika diperlukan.

Penyajian data, teknik ini memaparkan hasil temuan secara narasi.

Penarikan kesimpulan atau verifikasi, teknik ini peneliti berusaha agar dapat menggambarkan kerepresentatifan suatu peristiwa, kejadian atau suatu subjek.

Teknis analisis data dalam penelitian ini, adalah analisis data kualitatif yang dilakukan dalam tiga tahap, diantaranya:

$$
\text { 1. Analisis data pada saat }
$$
melakukan refleksi pada setiap siklus penelitian tindakan,

2. Analisis data terhadap hasil belajar atau prestasi belajar peserta didik dalam bentuk kuantitatif, dan

3. Analisis data berupa prosentase hasil belajar atau prestasi belajar yang diperoleh peserta didik dalam proses pembelajaran mata pelajaran IPS untuk Kelas IX.F, yang menggunakan strategi pembelajaran kooperatif type jigsaw.

Dalam kegiatan analisis data tersebut, akan didapatkan dua jenis data yaitu, data kualitatif dan data kuantitatif. Data kualitatif berupa hasil observasi yang dilakukan pada setiap siklus kegiatan, dan data kuantitatif berupa hasil belajar atau prestasi belajar yang didapatkan oleh peserta didik dalam melakukan proses pembelajaran IPS dengan menggunakan strategi pembelajaran kooperatif type jigsaw. Dari hasil belajar tersebut selanjutnya diprosentase ketercapaian hasil belajar dalam proses pembelajaran tersebut.

\section{IPARAN DATA DAN HASIL INELITIAN}

Paparan data merupakan deskripsi njabaran kegiatan penelitian yang akukan oleh peneliti selama melakukan nelitian. Dalam paparan data hasil nelitian ini, peneliti akan menjabarkan giatan yang direncanakan oleh peneliti ngan menjabarkan kegiatan per siklus yang d1raksanakan selama penelitian berlangsung. Penjabarannya adalah sebagai berikut: (a) siklus 1 , (b) siklus 2 .

\section{a. Siklus 1}

1). Tahap Perencanaan

Inti kegiatan pada siklus 1 adalah planning. Artinya perencanaan secara umum kegiatan pembelajaran dengan cara menyampaikan materi-materi yang akan dipelajari dalam proses belajar. Namun dalam kegiatan siklus 1 ini sudah dilakukan proses belajar mengajar yang dilakukan oleh peneliti sebagai guru mata pelajaran IPS Kelas IX.F.

Penyusunan instrument observasi juga dibuat untuk mengetahui keaktifan pelaksanaan pembelajaran dengan pembelajaran kooperatif tipe Jigsaw. Penyusunan instrumen yang digunakan yaitu lembar instrumen observasi guru dan lembar instrumen observasi peserta didik.

Sebelum perencanaan dilakukan, peneliti terlebih dahulu menyusun lembar observasi untuk melihat kelayakan yang telah dibuat dan disusun terhadap rencana pelaksanaan pembelajaran dan soal tes hasil belajar.

Tahap terakhir dalam perencanaan ini yaitu menetapkan kriteria keberhasilan pembelajaran. Dalam penelitian ini peserta didik dikatakan berhasil apabila nilai peserta didik mencapai kriteria ketuntasan minimal dengan nilai 70 .

\section{2). Tahap Pelaksanaan}

Pada siklus ini tindakan dilakukan selama 2 jam pertemuan dengan alokasi waktu 2 x 40 menit setiap pertemuan. Dalam melaksanakan strategi pembelajaran, guru mengemukakan orientasi dan prosedur kerja peserta didik sebagai kegiatan pembuka dengan memberikan materi pelajaran yang 
akan dipelajari. Adapun proses kegiatannya adalah sebagai berikut:

1. Kegiatan Pendahuluan

- Apersepsi guru memberikan pengantar bahwa bumi dibagi ke dalam beberapa bagian: daratan, perairan, dan udara; dilengkapi dengan contoh-contohnya, berapa jumlah benua dan samudera di bumi.

- Menyampaikan tujuan pembelajaran.

2. Kegiatan Inti

\section{Eksplorasi}

Dalam kegiatan eksplorasi, guru:

- Melibatkan peserta didik mencari informasi yang luas dan dalam tentang topik/tema materi yang akan dipelajari dengan menerapkan prinsip alam takambang jadi guru dan belajar dari aneka sumber;

- Dengan tanya jawab menyebutkan contohcontoh terjadinya perubahan sosial.

- Menggunakan beragam pendekatan pembelajaran, media pembelajaran, dan sumber belajar lain;

- Memfasilitasi terjadinya interaksi antarpeserta didik serta antara peserta didik dengan guru, lingkungan, dan sumber belajar lainnya;

- Melibatkan peserta didik secara aktif dalam setiap kegiatan pembelajaran; dan

- Memfasilitasi peserta didik melakukan percobaan di laboratorium, studio, atau lapangan

\section{Elaborasi}

Dalam kegiatan elaborasi, guru:

- Membagi siswa ke dalam 8 kelompok.

- Setiap kelompok membuka/menyiapkan atlas dunia dan buku sumber (atlas dan buku sumber bisa disiapkan oleh guru)

- Setiap kelompok mengkaji atlas dan buku sumber dengan bantuan Lembar Kerja untuk memperoleh kompetensi-mengenai posisiposisi benua-benua dan samudera, dan batasbatas wilayah geografis setiap benua dan samudera (Lembar Kerja terlampir)

- Siswa meminta dua kelompok secara bergantian untuk menyajikan hasil kerja kelompoknya di hadapan kelompokkelompok lain. Kelompok lain memberikan tanggapan.

- Kelas dibagi ke dalam beberapa kelompok, setiap kelompok terdiri dari 4 siswa (Kelompok Kooperatif)

- Guru membagi tugas, dimana setiap siswa dalam kelompok memperoleh tugas yang saling berbeda. Pembagian tugas sebagai berikut:

* Siswa pertama: mengidentifikasi karakteristik Benua Asia dan Eropa

* Siswa kedua : mengidentifikasi karakteristik Benua Afrika dan Amerika

* Siswa ketiga :mengidentifikasi karakteristik Benua Australia, Samudera Pasifik, dan Hindia

* Siswa keempat : mengidentifikasi karakteristik Samudera Pasifik dan Atlantik

- Siswa-siswa di berbagai kelompok yang memperoleh tugas yanag sama berhimpun menjadi satu (Kelompok Ahli)

- Kelompok ahli melakukan kajian buku sumber untuk memperdalam bidang tugasnya masing-masing.

\section{Konfirmasi}

Dalam kegiatan konfirmasi, peserta didik:

- Guru bertanya jawab tentang hal-hal yang belum diktahui siswa

- Guru bersama siswa bertanya jawab meluruskan kesalahan pemahaman, memberikan penguatan dan penyimpulan

\section{Kegiatan Penutup}

- membuat kesimpulan bersama-sama dari hasil diskusi.

- Guru menyampaikan informasi kepada siswa bahwa tugas diskusi belum selesai, dan akan dilanjutkan pada pertemuan yang akan datang

- melakukan penilaian

\section{3) Tahap Observasi}

Hasil observasi pada siklus I diperoleh gambaran tentang sikap dan perilaku peserta didik dalam hal kesungguhan peserta didik. Perhatian peserta didik mulai terpusat pada pelajaran walaupun belum maksimal. Sedangkan semangat peserta didik dalam mengikuti pelajaran IPS mulai meningkat. peserta didik lebih bersemangat jika dibandingkan dengan kondisi awal sebelum model pembelajaran partisipatif dengan teknik jigsaw diterapkan.

Dari hasil pelaksanaan siklus I pembelajaran kooperatif tipe Jigsaw tentang Benua dan Samudra di Bumi mata pelajaran IPS di kelas IX.F SMP Negeri 33 Surabaya Kota 
Penggunaan Metode Teknik Jigsaw dalam Upaya Meningkatkan Prestasi Belajar IPS Peserta Didik Kelas IXF SMPN 33 Surabaya Materi Benua dan Samudra di Bumi

Juliastuti

Surabaya diperoleh hasil penilaian tes hasil belajar yang telah dilakukan. Berikut ini merupakan hasil rekapitulasi penilaian hasil belajar peserta didik pada siklus I:

Tabel 4.1

Hasil Rekapitulasi Penilaian Hasil Belajar peserta didik

Siklus Ke I

\begin{tabular}{|c|c|c|c|c|c|}
\hline \multirow{2}{*}{ No } & \multirow{2}{*}{ Subyek } & \multirow{2}{*}{$\begin{array}{l}\text { Jml } \\
\text { Skor } \\
100\end{array}$} & \multirow{2}{*}{$\begin{array}{l}\text { Ketercap } \\
\text { aian }\end{array}$} & \multicolumn{2}{|c|}{$\begin{array}{l}\text { Ketuntas } \\
\text { an } \\
\text { Belajar }\end{array}$} \\
\hline & & & & Ya & $\begin{array}{l}\text { Ti } \\
\text { da } \\
\mathbf{k}\end{array}$ \\
\hline 141 & Almira Ose & 70 & $70,00 \%$ & $\sqrt{ }$ & \\
\hline 2 & Andik & 50 & $50,00 \%$ & & $\sqrt{ }$ \\
\hline 3 & $\begin{array}{l}\text { Ayu Milkhatus } \\
\text { Zahroh }\end{array}$ & 80 & $80,00 \%$ & $\sqrt{ }$ & \\
\hline 4 & $\begin{array}{l}\text { Azira Firsty } \\
\text { Agustin }\end{array}$ & 60 & $60,00 \%$ & & $\sqrt{ }$ \\
\hline 5 & $\begin{array}{l}\text { Ella Resti } \\
\text { Vausi }\end{array}$ & 50 & $50,00 \%$ & & $\sqrt{ }$ \\
\hline 6 & Ellyarosa S & 60 & $60,00 \%$ & 1 & $\sqrt{ }$ \\
\hline 7 & $\begin{array}{l}\text { Fourina } \\
\text { Octavia }\end{array}$ & 70 & $70,00 \%$ & $\sqrt{ }$ & \\
\hline 8 & Irma Wahyuni & 60 & $60,00 \%$ & & $\sqrt{ }$ \\
\hline 9 & $\begin{array}{l}\text { Lutvia Ninda } \\
\text { Kanti }\end{array}$ & 80 & $80,00 \%$ & $\sqrt{ }$ & \\
\hline 10 & $\begin{array}{l}\text { M. Deka Fajar } \\
\text { Nasarian }\end{array}$ & 60 & $60,00 \%$ & & $\sqrt{ }$ \\
\hline 11 & $\begin{array}{l}\text { Misbakhul } \\
\text { Chobibah }\end{array}$ & 70 & $70,00 \%$ & $\sqrt{ }$ & \\
\hline 12 & $\begin{array}{l}\text { Moch. Fadhil } \\
\text { Triputranto }\end{array}$ & 80 & $80,00 \%$ & $\sqrt{ }$ & \\
\hline 13 & $\begin{array}{l}\text { Mohammad } \\
\text { Adam Jourdan }\end{array}$ & 70 & $70,00 \%$ & $\sqrt{ }$ & c \\
\hline 14 & $\begin{array}{l}\text { Muhammad } \\
\text { Barron R }\end{array}$ & 60 & $60,00 \%$ & 0 & $\sqrt{ }$ \\
\hline 15 & $\begin{array}{l}\text { Muhammad } \\
\text { Rian Ibnu } \\
\text { Safril }\end{array}$ & 50 & $50,00 \%$ & & $\sqrt{ }$ \\
\hline 16 & $\begin{array}{l}\text { Nadya Ayu } \\
\text { Putri }\end{array}$ & 70 & $70,00 \%$ & $\sqrt{ }$ & \\
\hline 17 & $\begin{array}{l}\text { Novita Dian } \\
\text { Permatasari }\end{array}$ & 70 & $70,00 \%$ & $\sqrt{ }$ & \\
\hline 18 & $\begin{array}{l}\text { Nur Wachid } \\
\text { Ma'ruf }\end{array}$ & 50 & $50,00 \%$ & & $\sqrt{ }$ \\
\hline 19 & Olla Sucianti & 50 & $50,00 \%$ & & $\sqrt{ }$ \\
\hline 20 & Prada Alanosa & 60 & $60,00 \%$ & & $\sqrt{ }$ \\
\hline
\end{tabular}

\begin{tabular}{|c|c|c|c|c|c|}
\hline \multirow{2}{*}{ No } & \multirow{2}{*}{ Subyek } & \multirow{2}{*}{$\begin{array}{l}\text { Jml } \\
\text { Skor } \\
100\end{array}$} & \multirow{2}{*}{$\begin{array}{l}\text { Ketercap } \\
\text { aian }\end{array}$} & \multicolumn{2}{|c|}{$\begin{array}{l}\text { Ketuntas } \\
\text { an } \\
\text { Belajar }\end{array}$} \\
\hline & & & & Ya & $\begin{array}{l}\text { Ti } \\
\mathbf{d a} \\
\mathbf{k}\end{array}$ \\
\hline 21 & $\begin{array}{l}\text { Prita Dwi } \\
\text { Yuliana }\end{array}$ & 70 & $70,00 \%$ & $\sqrt{ }$ & \\
\hline 22 & $\begin{array}{l}\text { Putri } \\
\text { Megananda }\end{array}$ & 60 & $60,00 \%$ & & $\sqrt{ }$ \\
\hline 23 & $\begin{array}{l}\text { Rangga } \\
\text { DewanandaLa } \\
\text { musa }\end{array}$ & 60 & $60,00 \%$ & & $\sqrt{ }$ \\
\hline 24 & $\begin{array}{l}\text { Regina } \\
\text { Ananda Ayu } \\
\text { Saputi }\end{array}$ & 70 & $70,00 \%$ & $\sqrt{ }$ & \\
\hline 25 & $\begin{array}{l}\text { Reydo France } \\
\text { Juliano }\end{array}$ & 50 & $50,00 \%$ & & $\sqrt{ }$ \\
\hline 26 & $\begin{array}{l}\text { Septian Krisna } \\
\text { Surya M. }\end{array}$ & 50 & $50,00 \%$ & & $\sqrt{ }$ \\
\hline 27 & $\begin{array}{l}\text { Sidiq Abdul } \\
\text { GhaniKusuma }\end{array}$ & 60 & $60,00 \%$ & & $\sqrt{ }$ \\
\hline 28 & $\begin{array}{l}\text { Silvana Lavia } \\
\text { Ridha R }\end{array}$ & 60 & $60,00 \%$ & & $\sqrt{ }$ \\
\hline 29 & Siti Nadifah & 80 & $80,00 \%$ & $\sqrt{ }$ & \\
\hline 30 & Soim & 60 & $60,00 \%$ & & $\sqrt{ }$ \\
\hline 31 & Sujatmiko & 70 & $70,00 \%$ & $\sqrt{ }$ & \\
\hline 32 & Theo Krisna & 80 & $80,00 \%$ & $\sqrt{ }$ & \\
\hline 33 & $\begin{array}{l}\text { Tri Candra } \\
\text { Pranata }\end{array}$ & 70 & $70,00 \%$ & $\sqrt{ }$ & \\
\hline 34 & $\begin{array}{l}\text { Wisnu } \\
\text { Wisnawa } \\
\text { WijayaM. }\end{array}$ & 60 & $60,00 \%$ & & $\sqrt{ }$ \\
\hline 35 & $\begin{array}{l}\text { Yuniar } \\
\text { Fahmida }\end{array}$ & 70 & $70,00 \%$ & $\sqrt{ }$ & \\
\hline
\end{tabular}

\begin{tabular}{|c|l|c|}
\hline No & \multicolumn{1}{|c|}{ Uraian } & $\begin{array}{c}\text { Hasil } \\
\text { peserta } \\
\text { didik }\end{array}$ \\
\hline 1 & Nilai rata-rata & 64.00 \\
\hline 2 & Nilai tertinggi & 90 \\
\hline 3 & Nilai terendah & 60 \\
\hline 4 & $\begin{array}{l}\text { Jumlah peserta didik } \\
\text { yang tuntas }\end{array}$ & 16 \\
\hline 5 & $\begin{array}{l}\text { Jumlah peserta didik } \\
\text { yang tidak tuntas }\end{array}$ & 19 \\
\hline 6 & $\begin{array}{l}\text { Persentase peserta } \\
\text { didik yang tuntas }\end{array}$ & $45.71 \%$ \\
\hline 7 & $\begin{array}{l}\text { Persentase peserta } \\
\text { didik yang tidak tuntas }\end{array}$ & $54.29 \%$ \\
\hline 8 & Daya serap & $64.00 \%$ \\
\hline
\end{tabular}


Dari data di atas dapat diketahui bahwa dengan pembelajaran kooperatif tipe Jigsaw tentang Benua dan Samudra di Bumi pada mata pelajaran IPS di kelas SMP Negeri 33 Surabaya Kota Surabaya pada siklus I diperoleh nilai ratarata peserta didik yaitu 64.00. Dari 35 peserta didik, sebanyak 19 peserta didik yang tidak tuntas karena nilai yang diperoleh belum mencapai KKM yang diharapkan. Nilai KKM yang ditentukan sekolah yaitu 70 sehingga prosentase ketuntasan peserta didik yang diperoleh hanya sebesar $45.71 \%$, hal ini masih kurang dari kriteria yang diharapkan, karena belum mencapai KKM yang telah ditetapkan sekolah.

Tabel 4.2

Hasil Observasi Kegiatan peserta didik

Kegiatan Belajar Mengajar Siklus 1

\begin{tabular}{|c|c|c|}
\hline $\begin{array}{l}\mathbf{N} \\
\mathbf{0}\end{array}$ & $\begin{array}{l}\text { Kegiatan / Aspek Yang } \\
\text { Diamati }\end{array}$ & $\begin{array}{l}\text { Prose } \\
\text { ntase }\end{array}$ \\
\hline 1. & $\begin{array}{l}\text { Antusias peserta didik } \\
\text { dalam mengikuti KBM }\end{array}$ & $50 \%$ \\
\hline 2. & $\begin{array}{l}\text { Kelancaran } \\
\text { mengemukakan ide dalam } \\
\text { memecahkan masalah }\end{array}$ & $50 \%$ \\
\hline 3. & $\begin{array}{l}\text { Keaktifan peserta didik } \\
\text { dalam diskusi }\end{array}$ & $75 \%$ \\
\hline 4. & $\begin{array}{l}\text { Kemampuan dalam } \\
\text { menghimpun hasil diskusi }\end{array}$ & $50 \%$ \\
\hline 5. & $\begin{array}{l}\text { Ketelitian dalam } \\
\text { menghimpun hasil diskusi }\end{array}$ & $50 \%$ \\
\hline 6. & $\begin{array}{ll}\text { Keaktifan } & \text { dalam } \\
\text { membantu } & \text { teman dalam } \\
\text { diskusi } & \\
\end{array}$ & $50 \%$ \\
\hline 7. & Keaktifan dalam bertanya & $75 \%$ \\
\hline 8. & $\begin{array}{lr}\text { Keaktifan } & \text { dalam } \\
\text { menjawab menjawab } & \\
\text { pertanyaan guru } & \\
\end{array}$ & $75 \%$ \\
\hline 9. & $\begin{array}{l}\text { Keaktifan peserta didik } \\
\text { dalam mencari sumber } \\
\text { belajar }\end{array}$ & \\
\hline 10 & $\begin{array}{lr}\text { Kelancaran } & \text { peserta didik } \\
\text { dalam } & \text { menjawab } \\
\text { pertanyaan } & \\
\end{array}$ & $50 \%$ \\
\hline 11 & $\begin{array}{l}\text { Kentuntasan } \\
\text { menyelesaikan tugas }\end{array}$ & $75 \%$ \\
\hline 12 & $\begin{array}{l}\text { Keberanian } \\
\text { mempresentasikan hasil } \\
\text { tugas / diskusi }\end{array}$ & $75 \%$ \\
\hline & RATA-RATA & $\begin{array}{l}63,00 \\
\%\end{array}$ \\
\hline
\end{tabular}

Berdasarkan tabel keaktifan tersebut, menunjukkan bahwa situasi belajar di kelas

kurang menunjang keberhasilan belajar peserta didik. Sebab dari 35 peserta didik, diketahui yang aktif dalam memecahkan masalah dan menjawab pertanyaan dengan prosentase $75 \%$.

Pada umumnya peserta didik mulai berani mengemukakan pendapatnya, hal ini terlihat dari keaktifan peserta didik bertanya tentang materi yang belum dimengerti dan setiap peserta didik selalu berusaha menjawab pertanyaan dengan benar tanpa malu - malu lagi. Keberanian peserta didik juga semakin terlihat ketika harus tampil untuk membaca dan menjawab pertanyaan. Nilai ketepatan dalam menjawab pertanyaan rata-rata $75 \%$ dalam kategori tinggi. Sementara itu kemampuan dalam menghimpun hasil diskusirata-rata 50\% dalam kategori sangat baik. Secara keseluruhan tingkat aktifitas peserta didik adalah $63,00 \%$ termasuk kategori kurang.

Tabel 4.3

Hasil Observasi Kegiatan Guru Kegiatan Belajar Mengajar Siklus Ke I 
Data hasil pelaksanaan observasi aktifitas guru pada siklus I yang meliputi pendahuluan, kegiatan inti, penutup,

143 pengolahan waktu dan suasana kelas yang telah diamati selama proses pembelajaran diperoleh jumlah skor sebesar 28 dan skor maksimalnya 48 sehingga prosentase diperoleh sebesar 58,33\%. Dilihat dari tabel lembar observasi kegiatan guru selama proses pembelajaran masih banyak aspek dengan nilai 2 yang berarti cukup dan nilai 3 yang berarti baik. Selama proses pembelajaran berlangsung guru telah melaksanakan semua pembelajaran dengan baik. Meskipun ada beberapa aspek yang belum sempurna yakni guru kurang optimal mempersiapkan media pembelajaran dan guru kurang bisa mengefektifitaskan waktu yang telah ditentukan sehingga diperoleh prosentase sebesar $58,33 \%$ termasuk dalam kurang

\section{4)}

\section{Tahap Refleksi}

Berdasarkan pada kegiatan siklus 1 tersebut, peneliti melakukan refleksi dari hasil kegiatan tersebut. Berdasarkan pada observasi pada siklus 1 didapatkan temuan sebagai berikut: (1) peserta didik masih mengalami kebingungan dalam mempelajari materi yang disampaikan oleh guru, (2) peserta didik takut menyampaikan pendapat, dan (3) kegiatan diskusi kurang berjalan, masih didominasi oleh peserta didik yang pandai.

\section{b. Siklus 2}

\section{1) Tahap Perencanaan}

Setelah melakukan refleksi dan hasil analisis yang telah dilakukan pada siklus I, maka disusun siklus II dengan tahap perencanaan yaitu menyusun rencana pelaksanaan pembelajaran yang akan dilakukan pada siklus II dengan memperhatikan kekurangan yang terjadi pada siklus I agar siklus II pembelajaran menjadi lebih efektif dengan menggunakan pembelajaran kooperatif tipe Jigsaw. Rencana pelaksanaan pembelajaran juga dilengkapi dengan memberikan lembar kinerja kepada peserta didik yang digunakan dalam penerapan pembelajaran kooperatif tipe Jigsaw. Menyusun soal uji kompetensi dengan indikator kompetensi yang sama pada siklus

\begin{tabular}{|c|c|c|}
\hline No & Aspek yang diamati & Skor \\
\hline I & $\begin{array}{l}\text { Pelaksanaan } \\
\text { A. Pendahuluan } \\
\text { 1. Memotivasi peserta didik. } \\
\text { 2. Menyampaikan tujuan } \\
\text { pembelajaran } \\
\text { B. Kegiatan Inti } \\
\text { 1. Mendiskusikan langkah } \\
\text { kegiatan bersama peserta didik. }\end{array}$ & $\begin{array}{l}2 \\
2\end{array}$ \\
\hline & $\begin{array}{l}\text { 2. Membimbing peserta didik } \\
\text { melakukan kegiatan. } \\
\text { 3. Membimbing peserta didik } \\
\text { mendiskusikan hasil kegiatan } \\
\text { dalam kelompok. } \\
\text { 4. Memberikan kesempatan pada } \\
\text { peserta didik untuk } \\
\text { mempresentasikan hasil } \\
\text { penyelidikan. } \\
\text { 5. Membimbing peserta didik } \\
\text { merumuskan } \\
\text { /menemukan konsep. } \\
\text { C. Penutup } \\
\text { 1. Membimbing peserta didik } \\
\text { membuat rangkuman } \\
\text { 2. Memberikan evaluasi. }\end{array}$ & $\begin{array}{l}2 \\
3 \\
2\end{array}$ \\
\hline II & Pengelolaan waktu & 2 \\
\hline III & $\begin{array}{l}\text { Suasana Kelas } \\
\text { 1. Antusiasme kelas } \\
\text { 2. Guru Antusias }\end{array}$ & $\begin{array}{l}2 \\
3\end{array}$ \\
\hline \multicolumn{2}{|c|}{ JUMLAH } & 28 \\
\hline \multicolumn{2}{|c|}{ SKOR MAKSIMAL } & 48 \\
\hline \multicolumn{2}{|c|}{ PERSENTASE KEAKTIFAN } & $58,33 \%$ \\
\hline \multicolumn{2}{|c|}{ KRITERIA } & Kurang \\
\hline
\end{tabular}

sebelumnya sebagai penilaian dari hasil belajar peserta didik selama proses pembelajaran. Soal uji kompetensi berupa soal silangan yang terdiri dari 10 soal yang harus dijawab oleh peserta didik.

Penyusunan instrument observasi juga dibuat untuk mengetahui keaktifan pelaksanaan pembelajaran pada siklus II dengan pembelajaran kooperatif tipe Jigsaw. Penyusunan instrument yang digunakan pada siklus II yaitu lembar instrument observasi guru dan lembar instrument observasi peserta didik.

Tahap akhir dalam perencanaan ini yaitu menetapkan kriteria keberhasilan pembelajaran. Dalam penelitian ini peserta didik dikatakan berhasil apabila nilai peserta didik mencapai kriteria ketuntasan minimal dengan nilai 70 .

\section{2) Tahap Pelaksanaan}


Pada siklus ini rencana tindakan dilakukan selama 2 jam pertemuan dengan alokasi waktu 2 x 40 menit setiap pertemuan. Dalam melaksanakan strategi pembelajaran, guru mengemukakan orientasi dan prosedur kerja peserta didik sebagai kegiatan pembuka dengan memberikan materi pelajaran yang akan dipelajari. Pada kegiatan inti pelajaran, guru memberikan penjelasan tentang tujuan pembelajaran IPS dengan materi Benua dan Samudra di Bumi dengan sub pembahasan: 1 . Letak/posisi benua-benua dan samudera, 2 . Batas wilayah benua-benua dan samudera, 3 . Karakteristik benua-benua, 4. Karakteristik samudera-samudera, 5. Pembagian kawasan benua-benua, 6. Contoh negara-negara di berbagai kawasan benua

1.Kegiatan Pendahuluan

Apersepsi guru memberikan pengantar bahwa bumi dibagi ke dalam beberapa bagian: daratan, perairan, dan udara; dilengkapi dengan contoh-contohnya., berapa jumlah benua dan samudera di bumi.

pembelajaran.

Menyampaikan tujuan

\section{Kegiatan Inti}

\section{Eksplorasi}

Dalam kegiatan eksplorasi, guru:

- Melibatkan peserta didik mencari informasi yang luas dan dalam tentang topik/tema materi yang akan dipelajari dengan menerapkan prinsip alam takambang jadi guru dan belajar dari aneka sumber;

- Dengan tanya jawab menyebutkan contohcontoh terjadinya perubahan sosial.

- Menggunakan beragam pendekatan pembelajaran, media pembelajaran, dan sumber belajar lain;

- Memfasilitasi terjadinya interaksi antarpeserta didik serta antara peserta didik dengan guru, lingkungan, dan sumber belajar lainnya;

- Melibatkan peserta didik secara aktif dalam setiap kegiatan pembelajaran; dan

- Memfasilitasi peserta didik melakukan percobaan di laboratorium, studio, atau lapangan

\section{Elaborasi}

Dalam kegiatan elaborasi, guru:

Membagi siswa ke dalam 8 kelompok.

$>$ Setiap kelompok membuka/menyiapkan atlas dunia dan buku sumber (atlas dan buku sumber bisa disiapkan oleh guru)
Setiap kelompok mengkaji atlas dan buku sumber dengan bantuan Lembar Kerja untuk memperoleh kompetensi mengenai posisi-posisi benua-benua dan samudera, dan batas-batas wilayah geografis setiap benua dan samudera (Lembar Kerja terlampir)

$>$ Siswa meminta dua kelompok secara bergantian untuk menyajikan hasil kerja kelompoknya di hadapan kelompokkelompok lain. Kelompok lain memberikan tanggapan.

$>$ Kelas dibagi ke dalam beberapa kelompok, setiap kelompok terdiri dari 4 siswa (Kelompok Kooperatif)

Guru membagi tugas, dimana setiap siswa dalam kelompok memperoleh tugas yang saling berbeda. Pembagian tugas sebagai berikut:

$>$ Siswa pertama: mengidentifikasi karakteristik Benua Asia dan Eropa

Siswa kedua : mengidentifikasi karakteristik Benua Afrika dan Amerika

Siswa ketiga :mengidentifikasi karakteristik Benua Australia, Samudera Pasifik, dan Hindia

Siswa keempat : mengidentifikasi karakteristik Samudera Pasifik dan Atlantik

Siswa-siswa di berbagai kelompok yang memperoleh tugas yanag sama berhimpun menjadi satu (Kelompok Ahli)

Kelompok ahli melakukan kajian buku sumber untuk memperdalam bidang tugasnya masing-masing

\section{Konfirmasi}

Dalam kegiatan konfirmasi, guru:

> Membuat kesimpulan bersama-sama dari hasil diskusi.

> Guru menyampaikan informasi kepada siswa bahwa tugas disuksi belum selesai, dan akan dilanjutkan pada pertemuan yang akan datang

Melakukan penilaian

\section{3) Tahap Observasi}

Hasil observasi pada siklus II menunjukkan peningkatan yang cukup signifikan.Kesungguhan semangat peserta didik 
Penggunaan Metode Teknik Jigsaw dalam Upaya Meningkatkan Prestasi Belajar IPS Peserta Didik Kelas IXF SMPN 33 Surabaya Materi Benua dan Samudra di Bumi

Juliastuti

dalam mengikuti pelajaran IPS lebih meningkat. Seluruh peserta didik mengikuti pelajaran dengan penuh semangat, tidak ada yang malas atau kurang bersemangat dalam mengikuti pelajaran IPS.

Dari hasil pelaksanaan siklus II pembelajaran kooperatif tipe Jigsaw tentang bilangan ganjil dan bilangan genap mata pelajaran IPS di kelas II SMP Negeri 33 Surabaya Kota Surabaya diperoleh hasil penilaian tes hasil belajar yang telah dilakukan. Hasil yang didapatkan peserta didik mengalami peningkatan dibandingkan dengan hasil pada siklus I (terlampir). Berikut ini merupakan hasil rekapitulasi penilaian hasil belajar peserta didik pada siklus II:

Tabel 4.4

\section{Hasil Rekapitulasi Penilaian Hasil}

Belajar peserta didik

Siklus Ke II

\begin{tabular}{|c|c|c|c|c|c|}
\hline \multirow{2}{*}{ No } & \multirow{2}{*}{ Subyek } & \multirow{2}{*}{$\begin{array}{c}\text { Jumla } \\
\text { h } \\
\text { Skor } \\
100\end{array}$} & \multirow{2}{*}{$\underset{\mathbf{n}}{\text { Ketercapaia }}$} & \multicolumn{2}{|c|}{$\begin{array}{c}\text { Ketuntasan } \\
\text { Belajar }\end{array}$} \\
\hline & & & & Ya & $\begin{array}{c}\text { Td } \\
\mathbf{k}\end{array}$ \\
\hline 1 & Almira Ose & 80 & $80,00 \%$ & $\sqrt{ }$ & \\
\hline 2 & Andik & 80 & $80,00 \%$ & $\sqrt{ }$ & \\
\hline 3 & $\begin{array}{l}\text { Ayu } \\
\text { Milkhatus } \\
\text { Zahroh }\end{array}$ & 90 & $90,00 \%$ & $\sqrt{ }$ & \\
\hline 4 & $\begin{array}{l}\text { Azira } \\
\text { Firsty } \\
\text { Agustin }\end{array}$ & 70 & $70,00 \%$ & & \\
\hline 5 & $\begin{array}{l}\text { Ella Resti } \\
\text { Vausi }\end{array}$ & 80 & $80,00 \%$ & $\sqrt{ }$ & \\
\hline 6 & Ellyarosa S & 90 & $90,00 \%$ & $\sqrt{ }$ & \\
\hline 7 & $\begin{array}{l}\text { Fourina } \\
\text { Octavia }\end{array}$ & 90 & $90,00 \%$ & $\sqrt{ }$ & \\
\hline 8 & $\begin{array}{l}\text { Irma } \\
\text { Wahyuni }\end{array}$ & 70 & $70,00 \%$ & $\sqrt{ }$ & \\
\hline 9 & $\begin{array}{l}\text { Lutvia } \\
\text { Ninda } \\
\text { Kanti }\end{array}$ & 80 & $80,00 \%$ & $\sqrt{ }$ & \\
\hline 10 & $\begin{array}{l}\text { M. Deka } \\
\text { Fajar } \\
\text { Nasarian }\end{array}$ & 80 & $80,00 \%$ & $\sqrt{ }$ & \\
\hline 11 & $\begin{array}{l}\text { Misbakhul } \\
\text { Chobibah }\end{array}$ & 100 & $100,00 \%$ & $\sqrt{ }$ & \\
\hline 12 & $\begin{array}{l}\text { Moch. } \\
\text { Fadhil }\end{array}$ & 80 & $80,00 \%$ & $\sqrt{ }$ & \\
\hline
\end{tabular}

\begin{tabular}{|c|c|c|c|c|c|}
\hline \multirow{2}{*}{ No } & \multirow{2}{*}{ Subyek } & \multirow{2}{*}{$\begin{array}{c}\text { Jumla } \\
\text { h } \\
\text { Skor } \\
\mathbf{1 0 0}\end{array}$} & \multirow{2}{*}{$\underset{\mathbf{n}}{\text { Ketercapaia }}$} & \multicolumn{2}{|c|}{$\begin{array}{c}\text { Ketuntasan } \\
\text { Belajar }\end{array}$} \\
\hline & & & & Ya & $\begin{array}{c}\text { Td } \\
\mathbf{k}\end{array}$ \\
\hline & Triputranto & & & & \\
\hline 13 & $\begin{array}{l}\text { Mohamma } \\
\text { d Adam } \\
\text { Jourdan }\end{array}$ & 90 & $90,00 \%$ & $\sqrt{ }$ & \\
\hline 14 & $\begin{array}{l}\text { Muhamma } \\
\text { d Barron R }\end{array}$ & 70 & $70,00 \%$ & $\sqrt{ }$ & \\
\hline 15 & $\begin{array}{l}\text { Muhamma } \\
\text { d Rian Ibnu } \\
\text { Safril } \\
\end{array}$ & 70 & $70,00 \%$ & $\sqrt{ }$ & \\
\hline 16 & $\begin{array}{l}\text { Nadya Ayu } \\
\text { Putri }\end{array}$ & 70 & $70,00 \%$ & $\sqrt{ }$ & \\
\hline 17 & $\begin{array}{l}\text { Novita } \\
\text { Dian } \\
\text { Permatasari }\end{array}$ & 80 & $80,00 \%$ & $\sqrt{ }$ & \\
\hline 18 & $\begin{array}{l}\text { Nur } \\
\text { Wachid } \\
\text { Ma'ruf }\end{array}$ & 70 & $70,00 \%$ & $\sqrt{ }$ & \\
\hline 19 & $\begin{array}{l}\text { Olla } \\
\text { Sucianti }\end{array}$ & 70 & $70,00 \%$ & $\sqrt{ }$ & \\
\hline
\end{tabular}

\begin{tabular}{|c|c|c|c|c|c|}
\hline No & \multicolumn{4}{|c|}{ Uraian } & $\begin{array}{l}\text { Hasil } \\
\text { peserta } \\
\text { didik }\end{array}$ \\
\hline 1 & \multicolumn{4}{|c|}{ Nilai rata-rata } & 80,57 \\
\hline 2 & \multicolumn{4}{|l|}{ Nilai tertinggi } & 100 \\
\hline 3 & \multicolumn{4}{|c|}{ Nilai terendah } & 70 \\
\hline 4 & \multicolumn{4}{|c|}{ Jumlah peserta didik yang tuntas } & 35 \\
\hline 5 & \multicolumn{4}{|c|}{ Jumlah peserta didik yang tidak tuntas } & 0 \\
\hline 6 & \multicolumn{4}{|c|}{ Persentase peserta didik yang tuntas } & $100,00 \%$ \\
\hline 7 & \multicolumn{4}{|c|}{$\begin{array}{l}\text { Persentase peserta didik yang tidak } \\
\text { tuntas }\end{array}$} & $0,00 \%$ \\
\hline 8 & \multicolumn{4}{|c|}{ Daya serap } & $80,57 \%$ \\
\hline 20 & $\begin{array}{l}\text { Prada } \\
\text { Alanosa } \\
\end{array}$ & 100 & $100,00 \%$ & $\sqrt{ }$ & \\
\hline 21 & $\begin{array}{l}\text { Prita Dwi } \\
\text { Yuliana }\end{array}$ & 70 & $70,00 \%$ & $\sqrt{ }$ & \\
\hline 22 & $\begin{array}{l}\text { Putri } \\
\text { Megananda }\end{array}$ & 90 & $90,00 \%$ & $\sqrt{ }$ & \\
\hline 23 & $\begin{array}{l}\text { Rangga } \\
\text { Dewananda } \\
\text { Lamusa }\end{array}$ & 80 & $80,00 \%$ & $\sqrt{ }$ & \\
\hline 24 & $\begin{array}{l}\text { Regina } \\
\text { Ananda } \\
\text { Ayu } \\
\text { Saputri } \\
\end{array}$ & 70 & $70,00 \%$ & V & \\
\hline 25 & $\begin{array}{l}\text { Reydo } \\
\text { France } \\
\text { Juliano } \\
\end{array}$ & 80 & $80,00 \%$ & $\sqrt{ }$ & \\
\hline 26 & $\begin{array}{l}\text { Septian } \\
\text { Krisna } \\
\text { Surya M. }\end{array}$ & 70 & $70,00 \%$ & V & \\
\hline 27 & $\begin{array}{l}\text { Sidiq } \\
\text { Abdul } \\
\text { Ghani } \\
\text { Kusuma } \\
\end{array}$ & 90 & $90,00 \%$ & $\sqrt{ }$ & \\
\hline
\end{tabular}




\begin{tabular}{|c|l|c|c|c|c|}
\hline \multirow{2}{*}{ No } & Subyek & $\begin{array}{c}\text { Jumla } \\
\text { h } \\
\text { Skor } \\
\mathbf{1 0 0}\end{array}$ & $\begin{array}{c}\text { Ketercapaia } \\
\mathbf{n}\end{array}$ & \multicolumn{2}{|c|}{$\begin{array}{c}\text { Ketuntasan } \\
\text { Belajar }\end{array}$} \\
\cline { 5 - 7 } & & & & Ya & $\begin{array}{c}\text { Td } \\
\mathbf{k}\end{array}$ \\
\hline 28 & $\begin{array}{l}\text { Lavia } \\
\text { Ridha R }\end{array}$ & 70 & $70,00 \%$ & $\sqrt{ }$ & \\
\hline 29 & $\begin{array}{l}\text { Siti } \\
\text { Nadifah }\end{array}$ & 80 & $80,00 \%$ & $\sqrt{ }$ & \\
\hline 30 & Soim & 100 & $100,00 \%$ & $\sqrt{ }$ & \\
\hline 31 & Sujatmiko & 100 & $100,00 \%$ & $\sqrt{ }$ & \\
\hline 32 & $\begin{array}{l}\text { Theo } \\
\text { Krisna }\end{array}$ & 80 & $80,00 \%$ & $\sqrt{ }$ & \\
\hline 33 & $\begin{array}{l}\text { Tri Candra } \\
\text { Pranata }\end{array}$ & 90 & $90,00 \%$ & $\sqrt{ }$ & \\
\hline & $\begin{array}{l}\text { Wisnu } \\
\text { Wisnawa } \\
\text { Wijaya M. }\end{array}$ & 70 & $70,00 \%$ & $\sqrt{ }$ & \\
\hline 35 & $\begin{array}{l}\text { Yuniar } \\
\text { Fahmida }\end{array}$ & 70 & $70,00 \%$ & $\sqrt{ }$ & \\
\hline
\end{tabular}

Dari data di atas dapat diketahui bahwa dengan pembelajaran kooperatif tipe Jigsaw tentang Benua dan Samudra di Bumi pada mata pelajaran IPS di kelas IX.F SMP Negeri 33 Surabaya Kota Surabaya pada siklus II diperoleh nilai rata-rata peserta didik yaitu 80.57. Dari 35 peserta didik, sebanyak 35 peserta didik dinyatakan tuntas. Nilai KKM yang ditentukan sekolah yaitu 70 sehingga prosentase ketuntasan peserta didik yang diperoleh sebesar $100 \%$, jadi dapat diketahui dari hasil tiap peserta didik sudah mengalami ketuntasan karena nilai yang diperoleh peserta didik telah mengalami ketuntasan sesuai dengan KKM yang telah ditetapkan sekolah.

Tabel 4.5

Keaktifan Belajar peserta didik pada siklus 2

\begin{tabular}{|l|l|l|}
\hline No. & $\begin{array}{l}\text { Kegiatan / Aspek Yang } \\
\text { Diamati }\end{array}$ & Prosentase \\
\hline 1. & $\begin{array}{l}\text { Antusias peserta didik } \\
\text { dalam mengikuti KBM }\end{array}$ & $100 \%$ \\
\hline 2. & $\begin{array}{l}\text { Kelancaran } \\
\text { mengemukakan ide } \\
\text { dalam memecahkan } \\
\text { masalah }\end{array}$ & $75 \%$ \\
\hline 3. & $\begin{array}{l}\text { Keaktifan peserta didik } \\
\text { dalam diskusi }\end{array}$ & $100 \%$ \\
\hline 4. & $\begin{array}{l}\text { Kemampuan dalam } \\
\text { menghimpun hasil } \\
\text { diskusi }\end{array}$ & $75 \%$ \\
\hline 5. & $\begin{array}{l}\text { Ketelitian dalam } \\
\text { menghimpun hasil } \\
\text { diskusi }\end{array}$ & $75 \%$ \\
\hline
\end{tabular}

\begin{tabular}{|c|c|c|}
\hline No. & $\begin{array}{l}\text { Kegiatan / Aspek Yang } \\
\text { Diamati }\end{array}$ & Prosentase \\
\hline 6. & $\begin{array}{l}\text { Keaktifan dalam } \\
\text { membantu teman dalam } \\
\text { diskusi }\end{array}$ & $100 \%$ \\
\hline 7. & $\begin{array}{l}\text { Keaktifan dalam } \\
\text { bertanya }\end{array}$ & $100 \%$ \\
\hline 8. & $\begin{array}{l}\text { Keaktifan dalam } \\
\text { menjawab menjawab } \\
\text { pertanyaan guru }\end{array}$ & $100 \%$ \\
\hline 9. & $\begin{array}{l}\text { Keaktifan peserta didik } \\
\text { dalam mencari sumber } \\
\text { belajar }\end{array}$ & $100 \%$ \\
\hline 10. & $\begin{array}{l}\text { Kelancaran peserta didik } \\
\text { dalam menjawab } \\
\text { pertanyaan }\end{array}$ & $75 \%$ \\
\hline 11. & $\begin{array}{l}\text { Kentuntasan } \\
\text { menyelesaikan tugas }\end{array}$ & $100 \%$ \\
\hline 12. & $\begin{array}{l}\text { Keberanian } \\
\text { mempresentasikan hasil } \\
\text { tugas / diskusi }\end{array}$ & $75 \%$ \\
\hline & RATA-RATA & $90,00 \%$ \\
\hline
\end{tabular}

Berdasarkan tabel keaktifan dalam pembelajaran tersebut, menunjukkan bahwa situasi belajar di kelas ada peningkatan keaktifan dibandingkan dengan kegiatan pada siklus 1 . Pada siklus 2 ini, rata-rata keaktifan peserta didik diperoleh persentase $90,00 \%$. Kondisi demikian diharapkan akan menunjang keberhasilan belajar peserta didik.

Pada siklus 2 guru telah melakukan perbaikan secara nyata pada langkah- langkah kegiatan pembelajaran yaitu dengan memberikan pengarahan dan penegasan pada peserta didik. Guru juga terlihat semakin menguasai materi. Pada siklus 2 guru telah melaksanakan pembelajaran sesuai dengan rencana pelaksanaan pembelajaran yang direncanakan. Tidak terlihat lagi kelemahan guru pada proses pembelajaran siklus 2 sehingga guru terlihat semakin mantap dan semakin aktif. Peningkatan aktivitas guru dapat dilihat pada tabel berikut. 
Tabel 4.6

Hasil Observasi Kegiatan Guru Siklus Ke II

Keterangan skor :

1.: Kurang

2.: Cukup

3.: Baik

4.: Baik Sekali

Data hasil pelaksanaan observasi aktifitas guru pada siklus II yang meliputi persiapan, kegiatan awal, kegiatan inti, kegiatan akhir, pengolahan waktu dan suasana kelas yang telah diamati selama proses pembelajaran diperoleh jumlah skor sebesar 45 dan skor maksimalnya 48 sehingga prosentase diperoleh sebesar $93,75 \%$. Dilihat dari tabel lembar observasi kegiatan guru selama proses pembelajaran masih banyak aspek dengan nilai 3 yang berarti baik dan nilai 4 yang berarti sangat baik. Dilihat dari nilai yang didapat pada tiap aspek aktifitas guru selama proses pembelajaran terlihat adanya peningkatan pada siklus II. Guru menunjukkan kemampuannya secara maksimal dan dan kekurangan pada siklus I telah diperbaiki dengan memperhatikan refleksi pada siklus I, sehingga diperoleh prosentase sebesar $91,67 \%$ yang termasuk dalam kategori sangat baik.

Peningkatan prestasi belajar peserta didik ini menunjukkan bahwa prestasi belajar dipengaruhi oleh strategi belajar yang diberikan guru. Bagaimana guru dapat meningkatkan minat dan motivasi peserta didik dalam belajar, maka strategi yang cocok harus diterapkan oleh guru tersebut, sehingga dapat disimpulkan bahwa prestasi belajar dapat baik bila strategi yang diberikan oleh guru belajarnya juga baik.

Setelah melakukan kegiatan siklus 2 tersebut, peneliti melakukan refleksi dari hasil kegiatan tersebut. Berdasarkan pada observasi pada siklus 2 didapatkan temuan sebagai berikut: (1) sebagian peserta didik sudah ada peningkatan dalam memahami isi materi yang disampaikan oleh guru dibandingkan dengan kegiatan pada siklus 1, (2) beberapa peserta didik mulai berani menyampaikan pendapat dan tidak lagi didominasi oleh anak yang pandai, dan (3) kegiatan diskusi dapat berjalan lebih baik dibandingkan dengan kegiatan pada siklus
1, masih didominasi oleh peserta didik yang pandai.

\section{4) Tahap Refleksi}

Refleksi merupakan salah satu bagian penting dalam pembelajaran dengan pendekatan kontekstual (contextual learning

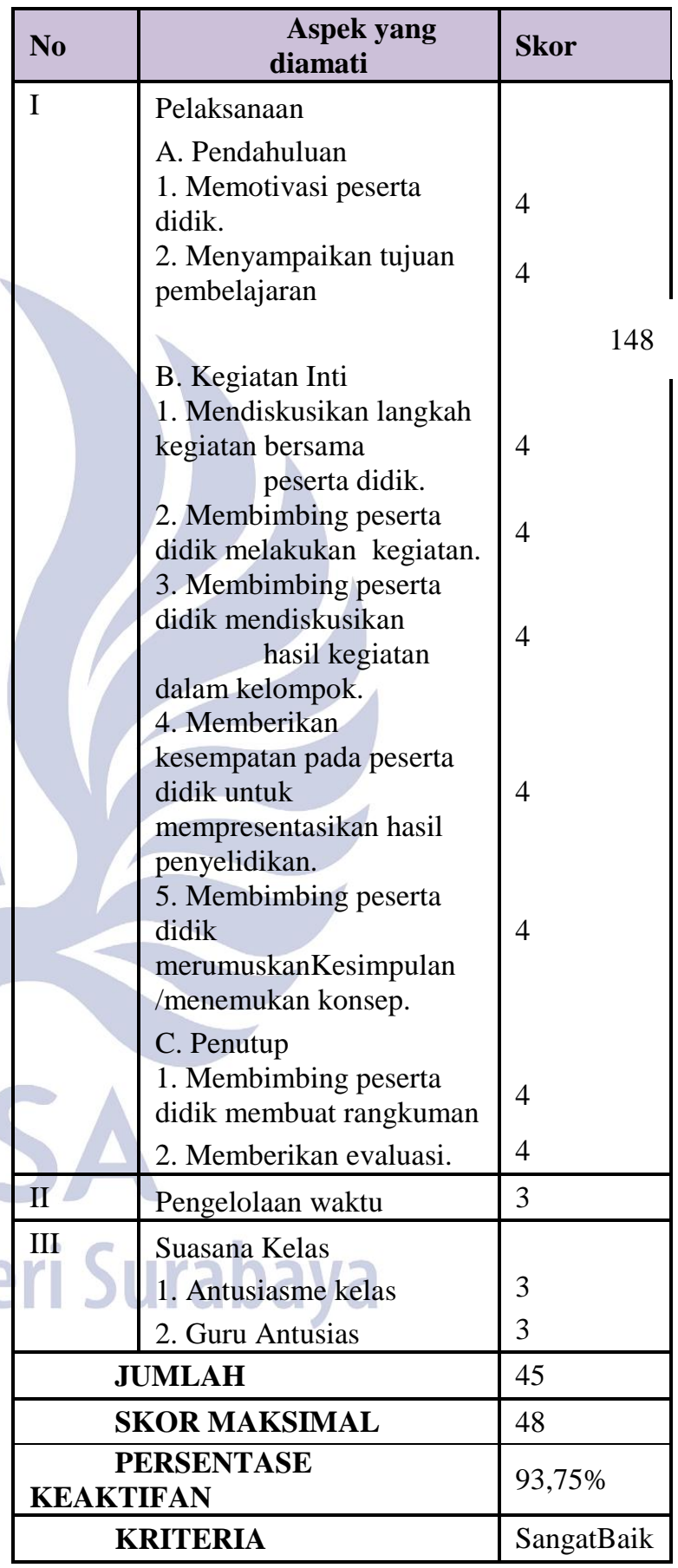

and teaching). Refleksi adalah cara berpikir tentang apa yang baru dipelajari atau berpikir ke belakang tentang apa-apa yang sudah dilakukan di masa lalu. peserta didik mengendapkan apa yang baru dipelajarinya, sebagai struktur pengetahuan yang baru, 
yang merupakan pengayaan atau revisi dari pengetahuan sebelumnya. Refleksi merupakan respon terhadap kejadian, aktivitas atau pengetahuan yang baru diterima.

Pengetahuan yang bermakna diperoleh dari proses. Pengetahuan yang dimiliki peserta didik diperluas melalui konteks pembelajaran, yang kemudian diperluas sedikit demi sedikit. Guru membantu peserta didik membuat hubungan pengetahuan yang dimiliki sebelumnya dengan pengetahuan yang baru. Dengan begitu peserta didik merasa memperoleh sesuatu yang berguna bagi dirinya tentang apa yang dipelajarinya. Kunci dari semua itu adalah bagaimana pengetahuan itu mengendap di benak peserta didik. peserta didik mencatat apa yang sudah dipelajarinya, dan bagaimana merasakan ideide baru.

Berdasar dari kegiatan penelitian dan hasil penelitian tindakan kelas, maka dalam pencapaian hasil belajar, ada beberapa peran yang dimiliki guru dalam upaya menyampaikan desain strategi pembelajaran dengan teknik jigsaw. Diantaranya: (1) membantu menciptakan lingkungan, sehingga peserta didik merasa bebas dalam berpikir dan menduga tanpa takut salah atau mendapat kritik, (2) menjelaskan dan mengilustrasikan bagaimana model dilaksanakan, membimbing keterampilan proses, membantu peserta didik menyatakan dan menganalisis hipotesis, serta mengartikulasi berpikir pada peserta didik, (3) mencatat proses untuk memonitor keputusan yang diambil oleh peserta didik dalam membuktikan hipotesisnya diterima atau tidak. Berkaitan dengan kegiatan guru dalam membimbing peserta didik, ada tiga cara penting yang harus dilakukan, (1) guru mendorong peserta didik berpikir yang dinyatakan dalam dalam bentuk hipotesis, (2) guru membantu membimbing berpikir peserta didik, seperti mereka membuktikan bahwa hipotesis diterima atau tidak, dan (3) guru menyuruh peserta didik untuk menjelaskan alasan pembuktian hipotesis.

Dan beberapa pernyataan tersebut di atas, berkaitan dengan penelitian tindakan kelas ini, yang memfokuskan pada peningkatan prestasi belajar peserta didik dengan strategi pembelajaran dengan teknik jigsaw, maka refleksi yang harus dipahami adalah menyadari bahwa teknik dapat dijadikan sebagai sebuah strategi pembelajaran yang dapat mendorong peserta didik untuk aktif dan kreatif, sehingga memungkinkan peserta didik untuk memunculkan motivasi peserta didik dalam mengikuti pelajaran dan pada akhirnya akan memperoleh hasil belajar yang optimal sesuai dengan tujuan pembelajaran. Namun keandalan teknik pembelajaran ini masih perlu dibuktikan dengan beberapa kali pengulangan dengan obyek yang berbeda, oleh karena itu percobaan dan penerapan model ini perlu dilakukan oleh berbagai pihak khususnya dalam bidang pengajaran.

Dengan proses pembelajaran tersebut ada beberapa hal yang dapat dilakukan guru untuk mengembangkan motivasi peserta didik secara optimal, diantaranya:

1. Peserta didik akan belajar jika mendapatkan motivasi dari guru. Hal itu dapat dilakukan oleh apabila guru: (a) menyediakan kegiatan yang menyenangkan, (b) memperhatikan keinginan mereka, (c) membangun pengertian melalui apa yang diketahui, (d) menciptakan suasana kelas yang mendukung dan merangsang belajar, (e) memberikan kegiatan yang sesuai dengan tujuan pembelajaran, (f) memberikan kegiatan yang menantang, (g) memberikan kegiatan yang memberi harapan keberhasilan, dan (h) menghargai setiap pencapaian peserta didik.

$2 . \quad$ Karena peserta didik mempunyai cara belajar yang berbeda, maka guru perlu: (a) berusaha mengetahui kelebihan dan kekurangan peserta didik, (b) merencanakan kegiatan yang sesuai dengan tingkat kemampuan peserta didik, (c) membangun pengetahuan dan keterampilan peserta didik yang diperoleh dari rumah maupun sekolah, dan (d) merencanakan dan menggunakan catatan kemajuan peserta didik.

3. Peserta didik belajar secara mandiri dan melalui kerjasama, untuk itu dalam mengemas pembelajaran guru harus memberikan kesempatan kepada peserta didik untuk: (a) belajar dalam kelompok sehingga peserta didik dapat terlatih kerjasama, (b) belajar secara klasikal memberikan kesempatan untuk saling menentukan gagasan, (c) memberikan kesempatan peserta didik untuk melakukan kegiatan secara mandiri, (d) melibatkan peserta didik dalam mengambil keputusan tentang kegiatan yang akan dilakukan, dan (e) belajar bagaimana cara belajar.

4. Peserta didik memerlukan konteks dan situasi yang berbeda dalam belajarnya, untuk itu dalam mengemas pembelajarannya guru harus: (a) menyediakan dan menggunakan berbagai alat peraga, (b) membelajarkan peserta didik untuk belajar IPS khususnya IPS diberbagai tempat dan kesempatan, (c) 
membelajarkan peserta didik menggunakan IPS-IPS untuk berbagai keperluan, (d) mengembangkan sikap peserta didik untuk menggunakan IPS sebagai alat untuk memecahkan masalah baik di rumah maupun di sekolah, dan (e) membantu peserta didik merefleksi kegiatan IPSnya.

Berdasarkan hasil penelitian tindakan yang dilakukan aleh peneliti, maka dapat direfleksikan proses kegiatan pembelajaran tersebut, dengan refleksi sebagai berikut:

1. Berdasarkan pada observasi pada siklus 1 didapatkan temuan sebagai berikut: (a) peserta didik masih mengalami kebingungan dalam mempelajari materi yang disampaikan oleh guru, (b) peserta didik takut menyampaikan pendapat, dan (c) kegiatan diskusi kurang berjalan, masih didominasi oleh peserta didik yang pandai.

2. Berdasarkan pada observasi pada siklus 2 didapatkan temuan sebagai berikut: (a) peserta didik sudah ada peningkatan dalam memahami isi materi yang disampaikan oleh guru dibandingkan dengan kegiatan pada siklus 1, (b) beberapa peserta didik mulai berani menyampaikan pendapat dan tidak lagi didominasi oleh anak yang pandai, dan (c) kegiatan diskusi dapat berjalan lebih baik dibandingkan dengan kegiatan pada siklus 1 , masih didominasi oleh peserta didik yang pandai.

3. Berdasarkan pada observasi pada siklus 3 didapatkan temuan sebagai berikut: (a) peserta didik sudah mengalami kemajuan yang baik dalam menerima dan menangkap materi yang disampaikan oleh guru, (b) banyak peserta didik yang sudah berani menyampaikan pendapat ketika diskusi kelas berlangsung, dan (c) kegiatan diskusi berjalan dengan baik, dan penyampaian pendapat tidak lagi didominasi oleh peserta didik yang pandai, mereka yang mempunyai kemampuan sedangpun berani menyampikan pendapatnya. Hal ini didorong oleh :motivasi guru pada kegiatan siklus 3 ini, dari pengalaman hasil refleksi kegiatan pada siklus sebelumnya.

4. Berdasarkan pada observasi yang dilakukan pada siklus sebelumnya dan pada siklus 4 didapatkan temuan sebagai berikut: (a) peserta didik sudah memahami dan siap dalam mempelajari materi yang disampaikan oleh guru, (b) sebagian besar dari peserta didik, sudah berani menyampaikan pendapat pada saat diskusi kelas berlangsung, dan (c) kegiatan berjalan dengan baik, suasana kelas lebih hidup, sehingga dalam proses pembelajaran terkesan menyenangkan.

\section{Pembahasan}

Lebih lanjut peneliti akan membahas beberapa fokus penelitian tindakan kelas yang telah dirumuskan, diantaranya: kelas IX.

$$
\text { 1. Proses pembelajaran IPS di SMP }
$$

Kenyataan di lapangan pendidikan SMP Negeri 33 Surabaya, proses belajar mengajar yang digunakan dalam proses kegiatan belajar

149 mengajar mata pelajaran IPS masih menggunakan strategi pembelajaran yang konvensional. Artinya kegiatan yang dilakukan oleh guru, belum menarik minat peserta didik dalam mencapai hasil belajar yang optimal.

Dengan fenomena tersebut, ada upaya yang dilakukan oleh beberapa guru agar hasil belajar peserta didik SMP Negeri 33 Surabaya khususnya Kelas IX.F dan umumnya kelas lainnya, yaitu dengan meningkatkan kualitas guru pengajar dan lebih menggunakan strategi belajar yang lebih bervariatif. Diantaranya menggunakan strategi pembelajaran dengan teknik jigsaw.

2. Prestasi belajar peserta didik dalam pelajaran IPS dengan menggunakan teknik jigsaw.

Upaya yang dilakukan guru dalam kegiatan belajar mengajar dengan menggunakan strategi pembelajaran dengan teknik jigsaw tersebut, ternyata membawa dampak yang positif terhadap prestasi belajar yang didapatkan oleh peserta didik, khususnya peserta didik Kelas IX.F SMP Negeri 33 Surabaya Kota Surabaya.

Hasil ini ditunjukan oleh peneliti, dari hasil penelitian tindakan kelas yang dilakukan. Dan hasil penelitian itu terdapat peningkatan hasil belajar yang signifikan yang didapatkan oleh peserta didik dalam belajar.

3. Dampak penggunaaan strategi teknik jigsaw dengan Prestasi Belajar.

Berdasarkan pada penjabaran fokus penelitian tersebut di atas, menunjukkan bahwa dampak yang diperoleh peserta didik dalam belajar IPS dengan menggunakan strategi pembelajaran teknik jigsaw sangat terlihat positif. Dengan demikian dapat dipastikan bahwa semakin kreatif guru dalam menggunakan strategi dalam kegiatan belajar mengajar, cenderung akan meningkatkan motivasi peserta didik dalam belajar, sehingga akan menghasilkan prestasi belajar yang optimal. 


\section{PENUTUP}

Berdasarkan pada hasil penelitian ini, dapat peneliti rumuskan beberapa kesimpulan, diantaranya (1) Strategi pembelajaran dengan teknik jigsaw dapat meningkatkan prestasi belajar peserta didik Kelas IX.F di SMP Negeri 33 Surabaya Kota Surabaya. Peningkatan prestasi belajar peserta didik ini menunjukkan bahwa motivasi belajar dipengaruhi oleh strategi belajar yang diberikan guru. Motivasi belajar yang tinggi cenderung akan mempengaruhi prestasi belajar yang tinggi pula. (2) Bukti peningkatan prestasi belajar peserta didik dari kegiatan pembelajaran dapat dijabarkan pada hasil kegiatan siklus 2 . Berdasarkan pada observasi yang dilakukan pada siklus sebelumnya dan pada siklus 2 didapatkan temuan sebagai berikut: (1) peserta didik sudah memahami dan siap dalam mempelajari materi yang disampaikan oleh guru, (2) sebagian besar dari peserta didik, sudah berani menyampaikan pendapat pada saat diskusi kelas berlangsung, dan (3) kegiatan berjalan dengan baik, suasana kelas lebih hidup, sehingga dalam proses pembelajaran terkesan menyenangkan. (3) Teknik Jigsaw salah satu komponen Contextual Teaching and Learning (CTL). Strategi ini dapat dilakukan pada semua mata pelajaran. (4) Strategi pembelajaran dengan menggunakan teknik Jigsaw dimungkinkan dapat meningkatkan prestasi belajar peserta didik Kelas IX.F di SMP Negeri 33 Surabaya pada mata pelajaran IPS.

Berdasarkan kesimpulan yang tersebut, maka dapat dirumuskan saran-saran sebagai berikut (1) Kepada guru SMP agar mempertimbangkan pemberian materi pembelajaran dengan mengenalkan kepada peserta didik dengan menggunakan berbagai macam strategi. Salah satunya adalah strategi pembelajaran yang digunakan adalah teknik jigsaw. (2) Kepada guru yang mengajarkan mata pelajaran IPS, hendaknya selalu mempunyai kreativitas dalam menggunakan strategi belajar yang diberikan kepada peserta didik. (3) Penggunaan teknik jigsaw dalam pembelajaran IPS sangat menguntungkan peserta didik. (4) Penggunaan teknik jigsaw pada tahap pemantapan, sangat bermanfaat untuk meningkatkan nilai-nilai ulangan harian. (5) Sistem dan cara penilaian yang dilakukan saat ini, kurang menguntungkan bagi pelaksanaan teknik jigsaw.

\section{DAFTAR PUSTAKA}

Arifin, I. 1998. Kepemimpinan Kepala Sekolah dalam Mengelola Madrasah Ibtidaiyauh dan SMP Berpretasi. Desertasi Tidak Dipublikasikan. Program Pascasarjana IKIP Malang

Arikunto, S. 2001 Dasar-Dasar Evaluasi Pendidikan. Jakarta: Penerbit Bumi Aksara

Bafadal, I. 1994. Proses Perubahan di sekolah. Desertasi Tidak Dipublikasikan. Program Pascasarjana IKIP Malang

Bogdan, R. C., \& Biklen, S. K. 1982. Qualitative Research In Educution. Boston: Allyn \& Bacon

Depdikbud, (1990). Peraturan Pelaksanaan Sistem Pendidikan Nasional. Jakarta: Armas Duta Jaya.

Guba, E. G., \& Lincoln, Y. S. 1981. Effective Evaluation. San Fransisco: Jossey-Bass Publishers

Hamalik, O. 2001. Proses Belajar Mengajar. Jakarta:PT Bumi Aksara

Hamalik, O. 2002. Perencanaan Pengajaran Berdasarkan Pendekatan Sistem. Jakarta: PT Bumi Aksara

Miles, M. B., \& Hubermen, A.M. 1984. Analisis Data Qualitatif. Terjemahan oleh Tjetjep Rohendi Rohidi. Universitas Indonesia, Jakarta

Moleong, L. J. 1995. Metodologi Penelitian Kualitatif. Bandung: PT. Remaja Rosdakarya.

Moleong, L. J. 2000. Metodologi Penelitian Kualitatif. Bandung: PT. Remaja Rosdakarya.

Nasution, S. 1988. Metode Penelitian Naturulistik Kualitatif. Bandung: Penerbit Tarsito

Nurhadi, \& Senduk, G., A., 2003. Pembelajaran Kontekstual dan Penerapannya dalam KBK. Malang: Universitas Negeri Malang.

Patton, Q. M. 1980. Qualitative Evaluations Methods. London: Sage Publications

Purwanto, Ngalim, M. 1995. llmu Pendidikan Teoritis dan Praktis. Edisi Kedua. Bandung : PT Remaja Rosdakarya 
Penggunaan Metode Teknik Jigsaw dalam Upaya Meningkatkan Prestasi Belajar IPS Peserta Didik Kelas IXF SMPN 33 Surabaya Materi Benua dan Samudra di Bumi Juliastuti

Fuskur, 2002. Kurikulum Berbasis Kompetensi. Jakarta: Balitbang Depdiknas

Santoso, B. 2002. Kurikulum Berbasis Kompetensi Jenjang SMP. Interpretasi Kegiatan Belajar Mengajar. Forum Pendidikan Dasar dan Menengah. Vol. 4 No. 3 \& 4:1524

Sidi, Djati, I. 2001. Menuju Masyarakat Belaja. Menggagas Paradigma Baru Pendidikan. Jakarta: Radar Jaya Offset.

Spradley, J., P. 1980. Participant Observation. New York: Holt, Rinehart and Winston

Sukmadinata, N.S. 2001. Pengembangan Kurikulum Teori dan Praktek. Bandung : PT Remaja Rosdakarya

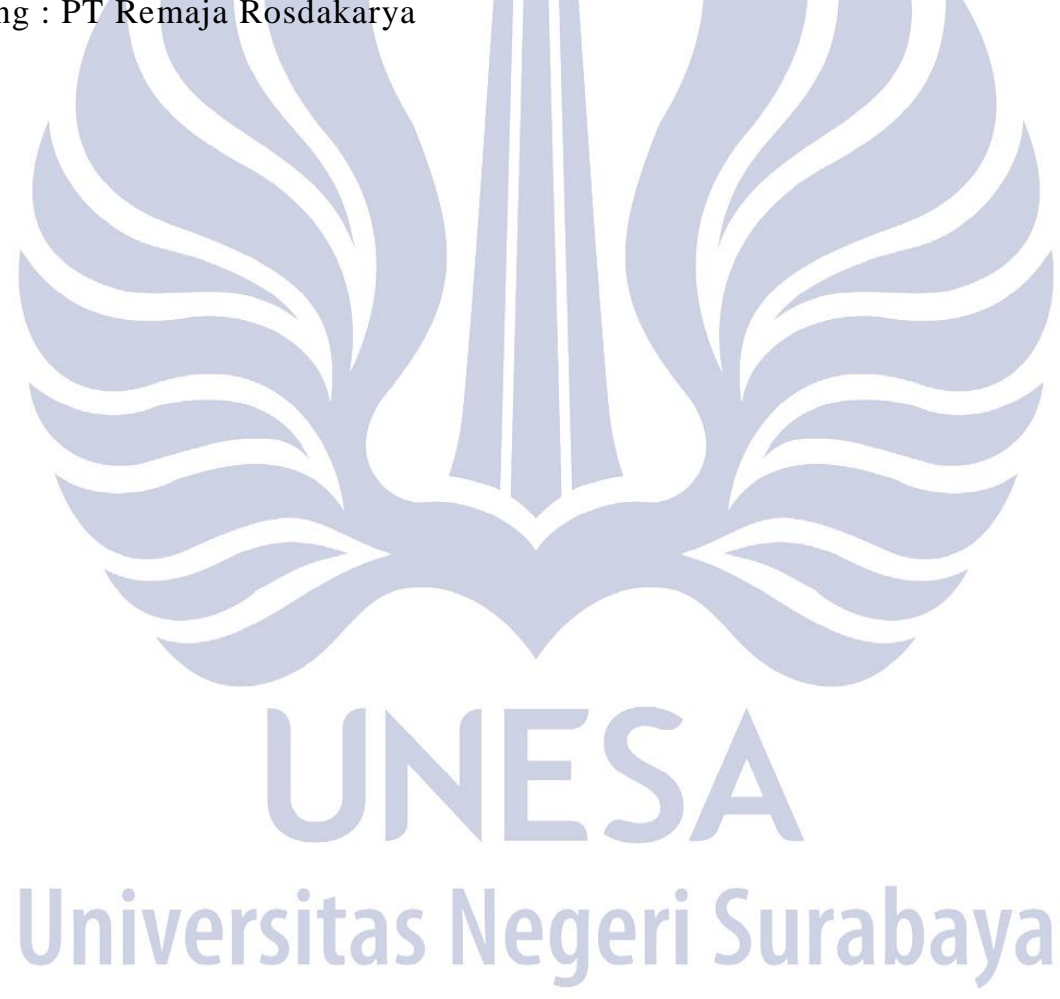

